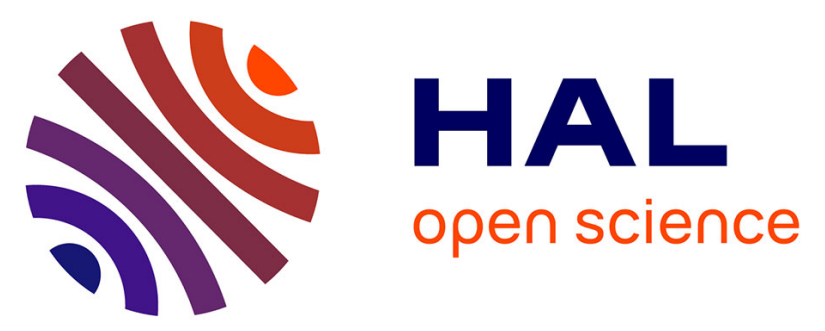

\title{
Recent and paleo-stresses at the northern margin of the Black-Sea and the Crimea Mountain in Meso-Ceonozoic-Quarternary (according to mechanisms of earthquakes foci and field tectonophysical data).
}

\author{
Anna Murovskaya, Jean-Claude Hippolyte, Y Shemeret, Tamara Yegorova
}

\section{To cite this version:}

Anna Murovskaya, Jean-Claude Hippolyte, Y Shemeret, Tamara Yegorova. Recent and paleo-stresses at the northern margin of the Black-Sea and the Crimea Mountain in Meso-Ceonozoic-Quarternary (according to mechanisms of earthquakes foci and field tectonophysical data).. Geofizičeskij žurnal, 2018, 40 (1), pp.243-244. 10.24028/gzh.0203-3100.v40i1.2018.124013 . hal-02324552

HAL Id: hal-02324552

https://hal.science/hal-02324552

Submitted on 7 Nov 2019

HAL is a multi-disciplinary open access archive for the deposit and dissemination of scientific research documents, whether they are published or not. The documents may come from teaching and research institutions in France or abroad, or from public or private research centers.
L'archive ouverte pluridisciplinaire HAL, est destinée au dépôt et à la diffusion de documents scientifiques de niveau recherche, publiés ou non, émanant des établissements d'enseignement et de recherche français ou étrangers, des laboratoires publics ou privés. 


\title{
Современные и палеонапряжения в пределах северной окраины Черного моря и Горного Крыма в мезо-кайнозое-квартере (по механизмам очагов землетрясений и полевым тектонофизическим Аанным)
}

\author{
(ㅇ А. Муровская ${ }^{1}$, Ж.-К. Ипполит ${ }^{2}$, Е. Шеремет ${ }^{1,3}$, Т. Егорова ${ }^{1}, 2018$ \\ ${ }^{1}$ Институт геофизики им. С.И. Субботина НАН Украины, Киев, Украина \\ ${ }^{2}$ Университет Аикс-Марсель, GEREGE UMR 34 CNRS-IRD, BP 80, \\ Аикс-ен-Прованс, Франция \\ ${ }^{3}$ Университет Ниццы-Софии Антиполис, CNRS, OCA-UMR Геоазур, \\ Вальбонн, Франция
}

Поступила 28 декабря 2017 г.

\begin{abstract}
Сучасні поля напружень на північній частині Чорного моря схарактеризовано на підставі 32 механізмів вогнищ землетрусів. Орієнтування осей стиснення у вогнищах засвідчують, що сучасний тектонічний процес відбувається переважно в умовах стиснення і транспресії. Аля 13 механізмів, розташованих у поясі між Південним берегом Криму та підошвою континентального склону, розраховано регіональне поле напружень, яке відображає деформаційний режим горизонтального стиснення у північно-західному-південно-східному напрямку. Наведено результати визначення полів палеонапружень і деформаційних режимів за даними польових тектонофізичних спостережень у 105 пунктах. Інтерпретацію виконано у межах двох загальних этапів: розтягу в ранній крейді та стиснення в кайнозої-кватері. Ао стадії кайнозойського стиснення віднесено поля напружень підкидного, покривного та зсувного типів. Побудовано генералізовані траєкторіi стиснення, які утворюють віялоподібний малюнок у дугоподібному секторі Південного берега Криму від м. Меганом до м. Аю-Ааг і змінюють свій напрямок від північ-південь до захід-схід. Розраховано осереднені поля напружень, які для Судацько-Феодосійської зони є підкідними, а для центральної и західної частин Гірського Криму зсувними. Південно-західна частина Гірського Криму характеризується полем напружень зсувного типу з південно-західним-північно-східним напрямком осі стиснення. На етапі крейдяного розтягу поля напружень були скидовими. Аля південно-західної частини Гірського Криму встановлено тенденцію розтягнення північнопівнічно-східного一південно-південно-західного напрямку, а для його центральної частини — північно-східного-південно-західного.
\end{abstract}

Ключові слова: Крим, Чорне море, механізми вогнищ землетрусів, поле напружень, деформаційний режим, кінематичний аналіз, кайнозойське стиснення.

Введение. Горный Крым (ГК) является западным завершением Крымско-Кавказского орогенного пояса и инвертированной частью северного шельфа Черно- го моря (ЧМ), в пределах которого обнажается полный стратиграфический разрез ЧМ [Nikishin et al., 2017], хранящий информацию о его истории. Авторы на- 
стоящей статьи рассматривают эволюцию ГК в рамках двух генерализованных этапов: мелового растяжения и кайнозойского сжатия, проявившихся во всем Циркум-Черноморском регионе и связанных с развитием Черноморского бассейна и окружающих его горных поясов.

Правомерность такого подхода подтверждается как геолого-структурными наблюдениями в пределах сухопутных окраин ЧМ, например, [Görür, 1997; Hippolyte et al., 2010, 2016; Муровская и Ар., 2014], так и сейсмическими исследованиями в его акватории [Баранова и др., 2008; Dinu et al., 2005; Khriachtchevskaia et al., 2010; Munteanu et al., 2011; Espurt et al., 2014; Starostenko et al., 2017]. Этап мелового растяжения связан с формированием сбросов и грабенов на большей части окраин ЧМ, а этап кайнозойского сжатия проявился в инверсионных деформациях меловых грабенов [Dinu et al., 2005; Khriachtchevskaia et al., 2010; Munteanu et al., 2011; Espurt et al., 2014].

Черноморский бассейн состоит из двух суббассейнов - восточного (ВЧБ) и западного (ЗЧБ), разделенных СрединноЧерноморским поднятием [ Туголесов и Ap., 1985; Finetti et al., 1988; Robinson et al., 1995; Афанасенков и др., 2007; Yegorova, Gobarenko, 2010; Nikishin et al., 2015a, b]. Горный Крым расположен между северозападным продолжением ВЧБ и северной окраиной ЗЧБ. Крымско-Кавказский орогенный пояс, частью которого является ГК, ограничен глубоководными прогибами: Coрокина и Туапсе на юге; Индоло-Кубанским и Западно-Кубанским на севере [Паталаха и др., 2003; Nikishin et al., 2017]. Эти бассейны заполнены мощными (болыше 5 км) глинистыми молассами майкопской серии, перекрытыми более молодыми отложениями [Finetti et al., 1988; Robinson et al., 1995; Nikishin et al., 2015a, b]. Накопление майкопских моласс по времени соответствует подъему и денудации Большого Кавказа (БК) и ГК, например [Афанасенков и Ap., 2007; Nikishin et al., 2015a, b].

С позиции плитовой тектоники ЧМ интерпретируется как задуговый бассейн, открывшийся над зоной северонаправленной субдукции палеоокеана Неотетис под южную окраину Евразии, например [Zonenshain, Le Pichon 1986; Finetti et al., 1988; Robinson et al., 1995; Okay, Nikishin, 2015 и ссылки в них]. Вопросы времени, последовательности и направления открытия ЧМ бассейнов остаются дискуссионными. "Медленное" раскрытие ЧМ в раннем мелу-палеоцене предполагается в работах [Zonenshain, Le Pichon, 1986; Finetti et al., 1988; Robinson et al., 1995]. B работе [Khriachtchevskaya et al., 2010] на основе сейсмических профилей ОГТ и пересмотра стратиграфии по скважинам сделан вывод об аптско-сантонском периоде рифтогенеза на северной окраине ЧМ. В работах [Nikishin et al., 2015a, b] период континентального рифтогенеза относится к позднему баррему-альбу, а раскрытие Черноморских глубоководных впадин с субокеанической корой происходит в сеномане-среднем сантоне. Рифтинг ЗЧБ и ВЧБ представляется одновременным (см. например, [Nikishin et al., 2015 a, b] или открытие ВЧБ предполагается позже, чем ЗЧМ, например в палеоцене [Finetti et al., 1988; Robinson et al., 1995].

Большинство предположений об эволюции ЧМБ основывается на интерпретации сейсмических профилей, где возрастная привязка глубоких сейсмических горизонтов не всегда базируется на данных бурения в силу больших мощностей (около 15 км) пострифтовых отложений, например [Yegorova, Gobarenko, 2010; Nikishin et al., 2015a,b]. В связи с этим изучение породных комплексов и их структурных соотношений в обнажениях ГК (инвертированная часть северного шельфа ЧМ) является исключительно важным и Ааже решающим для вопросов эволюции ЧM.

Этап кайнозойского сжатия в широком региональном контексте связан с коллизией нескольких континентальных микроплит - Киршехирской, Тавро-Анатолийской, Южно-Армянской, Арабской с южной окраиной Евразии [Finetti et al., 1988; Okay, Nikishin, 2015]. 
Роль и масштабы кайнозойской фразы сжатия в формировании складчато-наАвиговых деформаций в пределах ГК является темой дискуссии, как и наличие или отсутствие крупных горизонтальных перемещений. В классических работах Муратова, которые и сейчас остаются актуальными, не предполагается существенных горизонтальных перемещений [Myратов, 1969]. Представления о покровном строение верхнеюрско-нижнеберриасских отложений яйлы ГК разделяет ряд исслеАователей, например, [Милеев и др., 1998; Юдин, 2011 и ссылки в них]. В работе [Юдин, 2011] предложена надвиговая модель, в соответствии с которой ГК состоит из большого количества надвиговых пластин, тектонических меланжей и олистостром. В работе [Sheremet et al., 2016] представлены два разреза через восточную часть ГК и прогиб Сорокина, основным элементом которых также являются южновергентные надвиги.

Аискуссионным остается и вопрос о времени формирования деформаций сжатия в пределах ГК. Они развиты преимущественно в пределах Главной гряды Крымских гор, где самые молодые отложения относятся к титону-берриасу. Следовательно, обнаруженные в них деформации не старше этого возраста, но могут быть сколь угодно молодыми. Интересной представляется точка зрения [Бызова, 1980] о Авух этапах деформаций сжатия - киммерийском и альпийском, наложенных Аруг на Аруга в пределах Главной гряды ГК, в то время как Качинское поднятие, расположенное севернее, практически не затронуто кайнозойскими деформациями. Аналогичный вывод сделан и в работе [Saintot et al., 1999] на основе полевых тектонофизических работ в ГК.

В соответствие с новыми датировками таврического фрлиша как нижнемелового [Popadyuk et al., 2013; Sheremet et al., 2016а и ссылки в них], структуры сокращения к востоку от Караби-яйлы были отнесены авторами [Sheremet et al., 2016a] к кайнозойскому этапу деформации. Первая фаза сжатия в ГК, синхронная с глав- ной фазой дефрормации в Восточных Понтидах, завершилась до среднего эоцена [Sheremet et al., 2016b]. Это не противоречит представлениям о кайнозойской инверсии в пределах Судакского глубоководного трога [Nikishin et al., 2017 и ссылки в ней]. В Судакском троге главная фаза складчатости имела место на границе эоцена-олигоцена и в майкопское время - олигоцене-раннем миоцене, а главная фраза воздымания ГК произошла в послесарматский период. В работе [ ЮАин, 2011] Подгорный и Южнобережный меланжи в основании обрывов Главной гряды и вдоль береговой линии ЧМ аргументированно относятся к активным структурам неоген-четвертичного возраста.

Настоящая статья является продолжением тектонофизических исследований в пределах западной части Горного Крыма (ЗГК) [Муровская и Ар., 2014], где этап кайнозойского сжатия подтверждается сдвиговыми и надвиговыми деформациями в верхнемеловых-неогеновых пороАах. Этап растяжения в ЗГК начинается в валанжин-барремское время и достигает максимальной интенсивности в аптское. Он подтверждается конседиментационным сбросообразованием и формированием олистостромовых комплексов на протяжении практически всего раннего мела.

Аанное исследование сфокусировано на эволюции ГК и северной окраины ЧМ в мезо-кайнозое-квартере. Оно обобщает все наличные тектонофизические данные по ГК, собранные авторами за последние 20 лет, и все имеющиеся на данный момент механизмы очагов землетрясений Крымской сейсмогенной зоны (КСЗ), а также предлагает их интерпретацию в рамках двух генерализованных этапов: растяжения в раннем мелу и сжатия в кайнозое-квартере.

Современные поля напряжений охарактеризованы на основании механизмов очагов землетрясений КСЗ, которые собраны и обобщены с позиции поддвига Восточно-Черноморской микроплиты под Скифрскую плиту [Муровская и др., 2014; 
Гобаренко и Ар., 2016]. В данном исследовании авторы обновили данные по механизмам очагов, в соответствии с работой [Пустовитенко, Эреджепов, 2017], и поставили задачу установить связь современного поля напряжений по механизмам очагов с полями палеонапряжений по тектоническим зеркалам, изученным в обнажениях.

Актуальность изучения полей напряжений обусловлена повышенной сейсмической опасностью данного региона и его высоким углеводородным потенциалом. Особенности пространственного распределения деформаций и напряжений, а также их возрастная привязка необходимы в вопросах, касающихся геодинамической эволюции ЧМ и ГК.

Определение современного поля напряжений по механизмам очагов землетрясений. Северная окраина ЧМ характеризуется значительным уровнем сейсмической активности. Подавляющее большинство землетрясений КСЗ локализуется в полосе между Крымско-Кавказским побережьем и подошвой континентального склона, обозначая активную зону, где осуществляется современный тектонический процесс [Гобаренко и др., 2016]. Вдоль континентального склона ЧМ проходит надвиговый фрронт, маркирующий коллизионное взаимодействие Скифской плиты и Черноморской микроплиты [Finetti et al., 1988; Гобаренко и др., 2016]. Механизмы очагов сильных землетрясений КСЗ Аают возможность проанализировать особенности сейсмотектонического процесса в понятиях напряжений и деформационных режимов.

Методика. Определение современного поля напряжений по механизмам очагов землетрясений находится в поле научных интересов многих исследований, например, [Ребецкий, 2007; Vavrychuk, 2014; Гинтов и др., 2014]. Изначально интерпретация механизмов очагов землетрясений основывалась на представлениях о том, что ориентировка осей главных напряжений совпадает с ориентировкой Р и Т (кинематических) осей фокальных механиз- мов, например, [Балакина и др., 1972]. В работе [Костров, 1974] было показано, что с точки зрения механики сплошной среды такой подход заведомо предполагает совпадение сдвигового разрыва с плоскостью максимального касательного напряжения. Аля реальных процессов, проходящих в земной коре, сейсмогенные разрывы могут не совпадать с плоскостью максимального касательного напряжения, так как разрушение горных пород определяется не только величиной сдвиговых напряжений на плоскости разрыва, но и величиной нормальных напряжений на ней, создающих силы трения на этой плоскости [Byerlee, 1978]. Основное предположение, лежащее в основе современных методов определения поля напряжений по механизмам очагов землетрясений, заложено в гипотезе Волеса и Бота [Bott, 1959], суть которой состоит в том, что вектор перемещения по сейсмогенному разрыву совпадает с направлением разрешающего касательного напряжения на нем. Существует и другой подход к реконструкции поля напряжений по совокупности механизмов очагов землетрясений, основанный на определении осредненного положения Р и Т осей для группы землетрясений, которые отождествляются с главными осями тензора напряжений. Оба подхода реализованы в алгоритмах расчета поля напряжений как по тектоническим зеркалам, так и по механизмам очагов землетрясений и имплементированы в программу Вин Тензор [Delvaux, Sperner, 2003], которая применена в данной работе.

Аанные и результаты. В процессе многолетних сейсмологических исследований сотрудниками Отдела сейсмологии Института геофизики НАН Украины выполнено решение механизмов очагов сильных землетрясений $(M \geq 4)$, произошедших в пределах северной части ЧМ, включая КСЗ. Механизмы 31 землетрясения за период 1927-2013 гг. представлены в работе [Гобаренко и Ар., 2016], еще один механизм за 2016 г. - в работе [Пустовитенко, Эреджепов, 2017]. В настоящей статье 32 механизма обобщены и разделены 


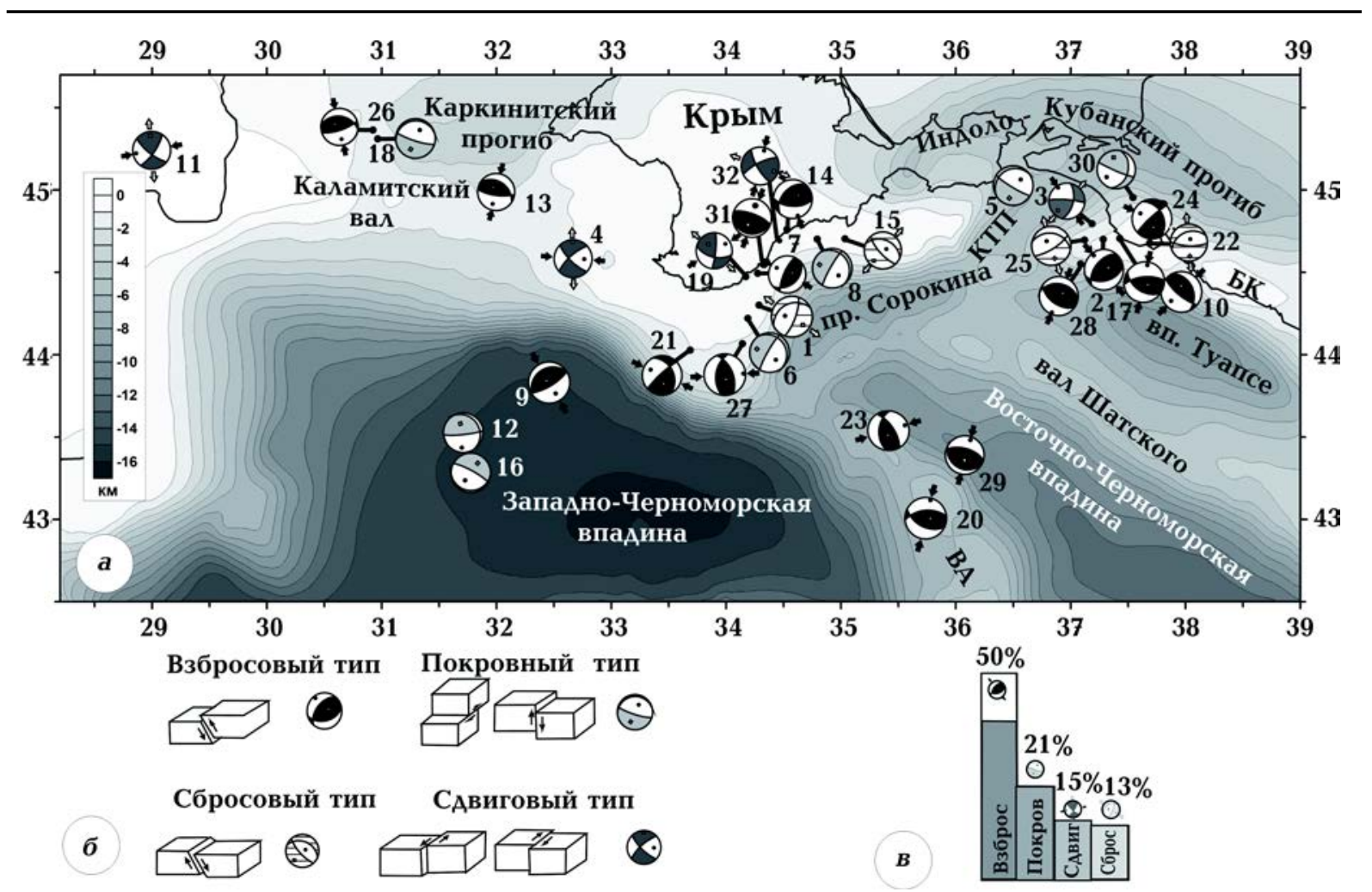

Рис. 1. Пространственное распределение и типизация механизмов очагов 32 землетрясений Крымской сейсмогенной зоны: $a$ - эпицентры сильных землетрясений и соответствующие им механизмы на фооне глубин кристаллического фундамента, по [Туголесов и др., 1985 ]; б - кинематические типы разрывов и соответствующие им механизмы очагов землетрясений; в - процентное соотношение механизмов разных типов. БК - Большой Кавказ, ВА - вал Андрусова, КТП - Керченско-Таманский прогиб.

на четыре группы в зависимости от ориентировок Р и Т осей (рис. 1).

Статистический анализ иллюстрирует присутствие механизмов всех типов при преобладании взбросового и покровного деформационных режимов. Выделение покровного деформационного режима предложено в работе [Паталаха и др., 2003], в работе [Гинтов, 2005] он называется "режимом, связанным с перемещением по горизонтальной плоскости".

Аля 13 механизмов, расположенных непосредственно вдоль южного побережья Крыма в пределах Южно-Крымского наАвигового фронта, был выполнен статистический анализ ориентировок Р и Т осей, рассчитано региональное поле напряжений и соответствующий ему средний механизм (рис. 2).

Методика определения среднего механизма представлена в работе [Ребецкий,
2007]. Во всех полученных статистических результатах очевидно преобладание северо-западно-юго-восточных направлений (рис. 2,б-г). Максимумы ориентировок Р и Т осей свидетельствуют о преобладании наклонных положений осей северо-западных и юго-восточных погружений (см. рис. 2, б), что характерно дмя перемещения по поверхности горизонтального детачмента [Гинтов, 2005; Ребецкий, 2007]. Региональное поле напряжений, в котором могли осуществиться смещения по всем нодальным площадкам 13 фокальных механизмов, отражает деформационный режим горизонтального сжатия в северо-западно-юго-восточном направлении (см. рис. 2, в). Аля известных ориентировок главных осей регионального поля напряжений рассчитан средний механизм (см. рис. 2, г). Обе нодальные плоскости среднего механизма, который от- 
носится к взбросовому типу, ориентированы в северо-восточном направлении и субортогональны простиранию КСЗ в районе Южного берега Крыма. Все перечисленные результаты отражают генерализованный процесс сжатия и укорочения в северо-западном направлении, при том что перемещения по отдельным нодальным плоскостям реализуются в различных направлениях, что связано с изменением во времени и пространстве полей напряжений второго порядка.

Определение полей палеонапряжений по анализу тектонических зеркал с борозАами скольжения. Систематическое тектонофизическое изучение ГК было нача-

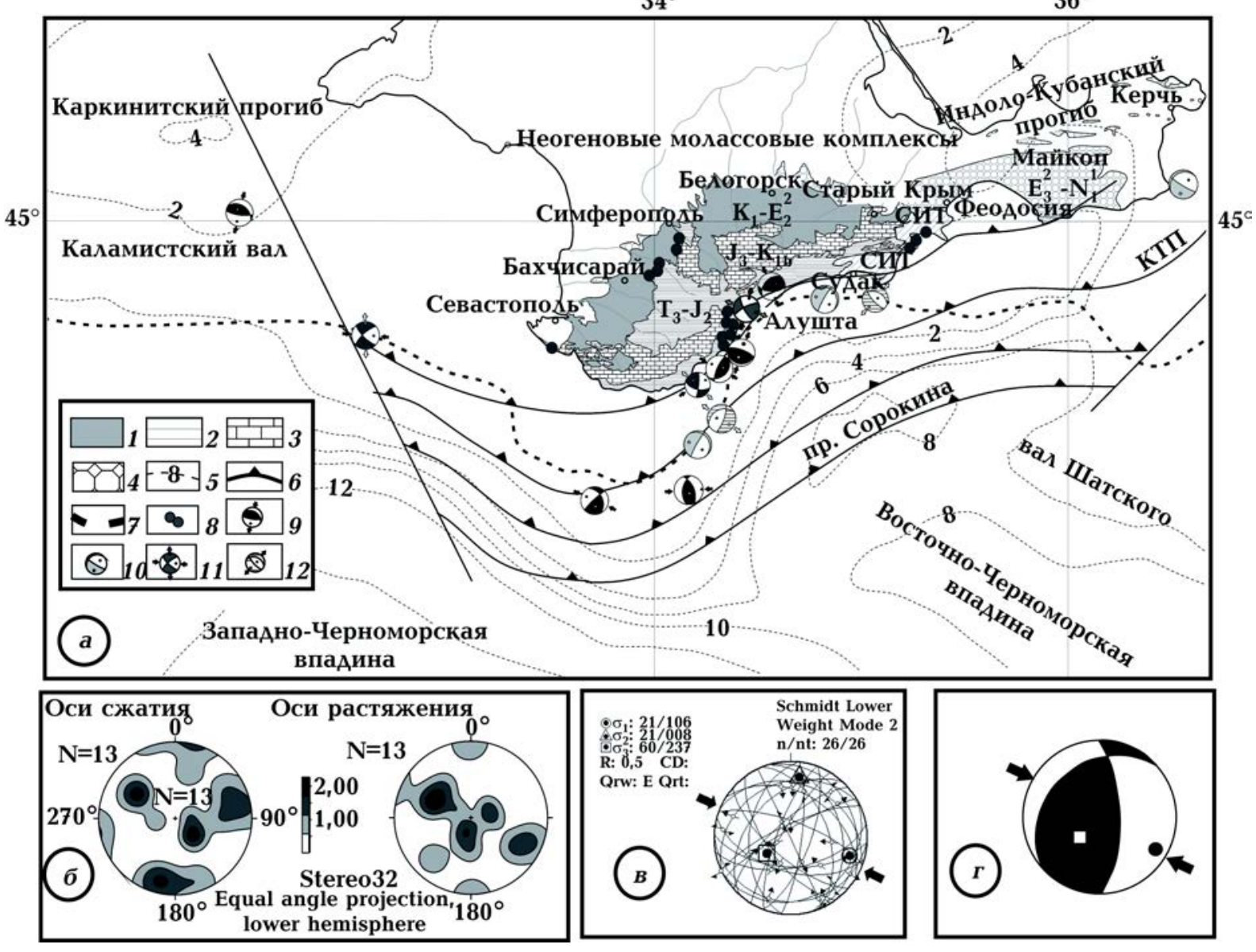

Рис. 2. Положение 13 механизмов очагов землетрясений КСЗ и их анализ: $a$ - тектоническая схема Горного Крыма и прилегающей окраины Черного моря, по [Муратов, 1969; Finetti et al., 1987; Nikishin et al., 2017; Туголесов и др., 1985; Гобаренко и др., 2016]. Геологические комплексы в пределах ГК: 1 - флишевые и вулканогенно-осадочные комплексы верхнего триаса-средней юры; 2 - шельфовые известняки и конгломераты верхней юры-берриаса; 3 - терригенные и карбонатные отложения нижнего мелаэоцена; 4 - отложения глубоководного молассового бассейна олигоцена-нижнего миоцена (СИТ Судакский инвертированный трог); 5 - крупные выходы магматических пород средней юры-берриаса; 6 -8 - структурные элементы северной окраины Черного моря: 6 - глубина залегания домелового фундамента; 7 - подошва континентального склона; 8 - Южно-Крымский надвиговый фронт и ограничивающий его с запада Одесско-Синопский разлом; 9-12- положение и механизмы очагов землетрясений с $M>4: 9-$ взбросового типа; $10-$ покровного типа; 11 - сдвигового типа; 12 - сбросового типа; КТП - Керченско-Таманский прогиб; б - стереограммы ориентировок Р и Т осей 13 механизмов очагов землетрясений; в - поле напряжений, рассчитанное для 13 механизмов очагов землетрясений методом правой дигетры [Delvaux, Sperner, 2003]; $г$ - средний механизм для 13 механизмов очагов землетрясений, рассчитанный по полю напряжений на рис. 2, в. 
то в 1989 г. сотрудниками отдела тектонофизики ИГФ НАН Украины под руководством О.Б. Гинтова. На основании исследований группы были выделены 24 этапа деформации в пределах ГК на протяжении мезозоя и кайнозоя [Гинтов, 2005]. Ю. М. Вольфман поставил восстановленные по тектонофизическим данным поля напряжений в соответствие периодам трансгрессий - регрессий в пределах Крыма и Северного Причерноморья и обосновал цикличность смены их ориентировок [Вольфман, 2015].

В работе [Saintot et al., 1999] поля напряжений, определенные по тектоническим зеркалам (структурам мезоуровня), поставлены в соответствие с кинематикой региональных разломов (структур макроуровня) и предложена идея о нескольких генерализованных этапах деформации.

В.В. Гончар проводил многолетние тектонофизические исследования в ГК. На основании обобщения всех имеющихся геофизических данных и с помощью математического моделирования методом конечных элементов он обосновал коллизионную модель Крымского орогена [Гончар, 2013] и механизм латеральной экструзии земной коры ГК [Гончар, 2015].

В перечисленных исследованиях сделаны различные выводы, в первую очередь относительно количества и последовательности этапов деформации, что свидетельствует, что этот вопрос все еще остается открытым.

Методика. Как показали эти и другие тектонофизические исследования, наиболее значительной проблемой при работе с полями напряжений является их временная привязка и тектоническая интерпретация. Аостаточно остро эта проблема стоит для ГК, где подавляющее большинство зеркал скольжения было обнаружено в относительно древних породах (от позднего триаса до раннего мела), что само по себе позволяет предполагать возрастные рамки деформации от позднего триаса до современности. Также было показано на большом количестве фрактического материала по механизмам очагов зем- летрясений, например для сейсмогенной зоны Загроса [Гинтов и Ар., 2014], что типы и направления полей напряжений при современном тектогенезе могут изменяться очень быстро (в течение нескольких лет). Это не всегда делает корректным выделение отдельных этапов деформации по ориентировкам или типам полей напряжений. Многочисленные эксперименты по аналоговому моделированию также показывают наличие полей напряжений разных порядков и типов, а также их изменение даже в ходе одного модельного эксперимента без изменений условий нагружения, например, [Осокина, Фридман, 1987].

Поэтому мы привязали поля напряжений ко времени и выполнили их интерпретацию в тесной связи с нашими геолого-структурными наблюдениями и региональным тектоническим контекстом. Особенность нашего методологического подхода - интерпретация полей напряжений в рамках двух генерализованных этапов: растяжения в раннем мелу и сжатия в кайнозое-квартере, временные рамки которых получены независимыми от тектонофизики методами. Впервые такой подход обоснован и применен в работе [Муровская и Ар., 2014] Аля ЗГК.

При полевых работах использовался весь арсенал геолого-структурных и тектонофизических методов. Обработка и интерпретация зеркал скольжения и механизмов очагов землетрясений осуществлялась кинематическим методом с применением программы Win Tensor [Delvaux, Sperner, 2003]. Представление тектонических зеркал и осей главных нормальных напряжений выполнялось на проекции нижней полусферы (сетке Вульфа). В соответствии с ориентировкой главных осей поля напряжений разделили, аналогично механизмам землетрясений, на четыре группы: взбросовые, сбросовые, сдвиговые и покровные.

Аанные и результаты. В табл. 1 и 2 представлены результаты определения полей напряжений и деформационных режимов Аля 105 пунктов наблюдения. Аля удобства ГК разделен на западную (ЗГК) и вос- 
точную (ВГК) части по линии Симферополь-Алушта и используется самостоятельная нумерация обнажений для каждой из частей.

На основании дешифрирования космоснимков и наших полевых наблюдений [Sheremet, 2016а] составлена схема разломов ГK на фоне 3D-рельефа, в каждой точке наблюдения вынесены ориентировки действующих осей (осей сжатия для взбросовых, покровных и сдвиговых деформационных режимов и осей растяжения для сбросовых деформационных режимов). На рис. 3, а представлены ориентировки осей сжатия в соответствующих пунктах наблюдений для полей взбросового и покровного типа.

Аалее были проведены линии (траектории) субпараллельно осям сжатия, которые демонстрируют направление сокращения. Направление траекторий сжатия различно на разных участках изученной территории и в целом образует веерообразный рисунок в наиболее прогнутой части ГК от м. Аю-Ааг до м. Меганом. Аналогичным образом вынесены оси сжатия для сАвиговых дефрормационных режимов и проведены субпараллельные им траектории (рис. 3, б). Рисунок траекторий сжатия для сдвиговых полей подобен таковому для полей взбросового типа. Параллельность траекторий сжатия для обоих деформационных режимов позволила проинтерпретировать их совместно и причислить к общему этапу деформации.

Этап кайнозойского сжатия. Мы связываем поля напряжения взбросового, покровного и сАвигового типов с этапом кайнозойского сжатия. Подобный рисунок осей сжатия для данных полей позволил объединить их на одной схеме и провести траектории сжатия, которые на языке деформации показывают направление сокращения (рис. $3, B_{,} \Gamma$ ). В центральной части ГК преобладает юго-восточная ориентировка траекторий сжатия. К востоку от центра направление сжатия изменяется на меридиональное, а к западу становится северо-восточным, формируя веерообразный рисунок в наиболее прогнутой части ГК от м. Аю-Ааг до м. Меганом. Мы связываем такое распределение траекторий сжатия с дугообразной (выпуклой на северо-запад) формой надвигового фрронта. Юго-западная часть ГК характеризуется юго-западным-северо-восточным направлением сжатия.

Аля участков с однородными по направлению осями сжатия построены осредненные поля напряжений. В самой восточной части ГК (Судакско-Феодосийской зоне (СФЗ)) осредненные поля напряжений относятся к взбросовому типу, а Аля центральной и западной частей ГК они представлены сдвиговыми типами (рис. 3, в, г).

Геолого-структурные наблюдения, выполненные в ГК в рамках IRG проекта (2013-2017) позволили описать и закартировать многочисленные структуры сокращения, отраженные на структурной карте и разрезах [Sheremet et al., 2016 b] и связанные с деформационными режимами сжатия. Такого рода структуры (асимметричные антиклинальные принадвиговые складки, шевронные складки, зоны надвигов, тектонические зеркала взбросового типа и Ар.) наиболее типичны для СФЗ (рис. 4, a).

В центральной и западной частях Главной гряды Крымских гор в зоне развития яйл (в целом моноклинально залегающих известняковых массивов оксфорд-берриасского возраста) [Nikishin et al., 2017 и ссылки в ней] преобладают разрывные нарушения сАвигового типа по крутопадающим разрывам, сопряженные с горизонтальными перемещениями по пологим плоскостям напластования или стратиграфических контактов.

Надвиговые структуры зафиксированы в районе Южного берега Крыма на контактах различных по реологии породных комплексов, один из которых - Балаклавский надвиг (табл. 2, п. 2) - впервые описан в работе [Гинтов, 2005] и продемонстрирован на рис. $4, a$, б. Взбросовые зеркала скольжения зафиксированы также вдоль краевого взброса, ограничивающего известняковые массивы Главной гряды с севера (например, в Узунджинском 
каньоне, в долине р. Бельбек, в районе с. Плотинное, в диабазовых карьерах в районе с. Счастливое и т. А. (см. табл. 2, п. $25,31,35)$ ).
Этап мелового растяжения. Было получено значительное количество полей напряжения сбросового типа с различными ориентировками действующей оси растя-
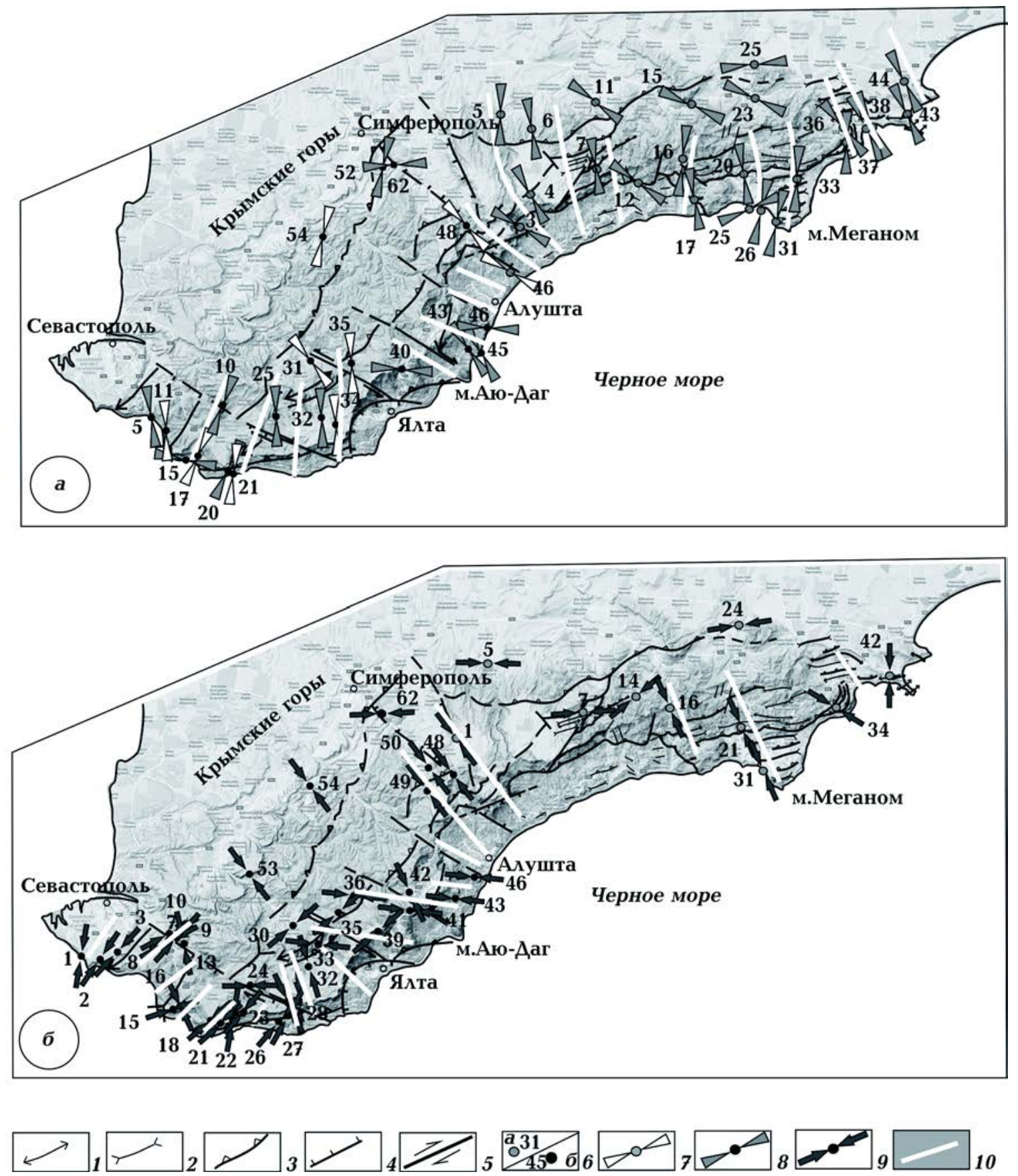

Рис. 3. Построение траекторий сжатия для кайнозойского этапа эволюции Горного Крыма: $a-$ ориентировки осей и траекторий жатия для полей взбросового и покровного типов на фоне построенной схемы разломов; б - ориентировка осей и траекторий сжатия для полей сдвигового типа; в - ориентировка осей и траекторий сжатия для суммы полей взбросового, покровного и сдвигового типов; средние поля напряжений показаны вдоль берега ГК; направление внешнего воздействия показано стрелками; 1, 2 - оси антиклинальных (1) и синклинальных (2) складок; разрывные 
жения, которые представлены на рис. 5. Некоторые из изученных сбросовых разрывов на основе наших геолого-структурных наблюдений определены как консе- диментационные и "работавшие" в раннемеловое время [Муровская и др., 2014]. Система параллельных сбросов СЗ 290$300^{\circ}$ ориентировки пересекает верхнеюр-
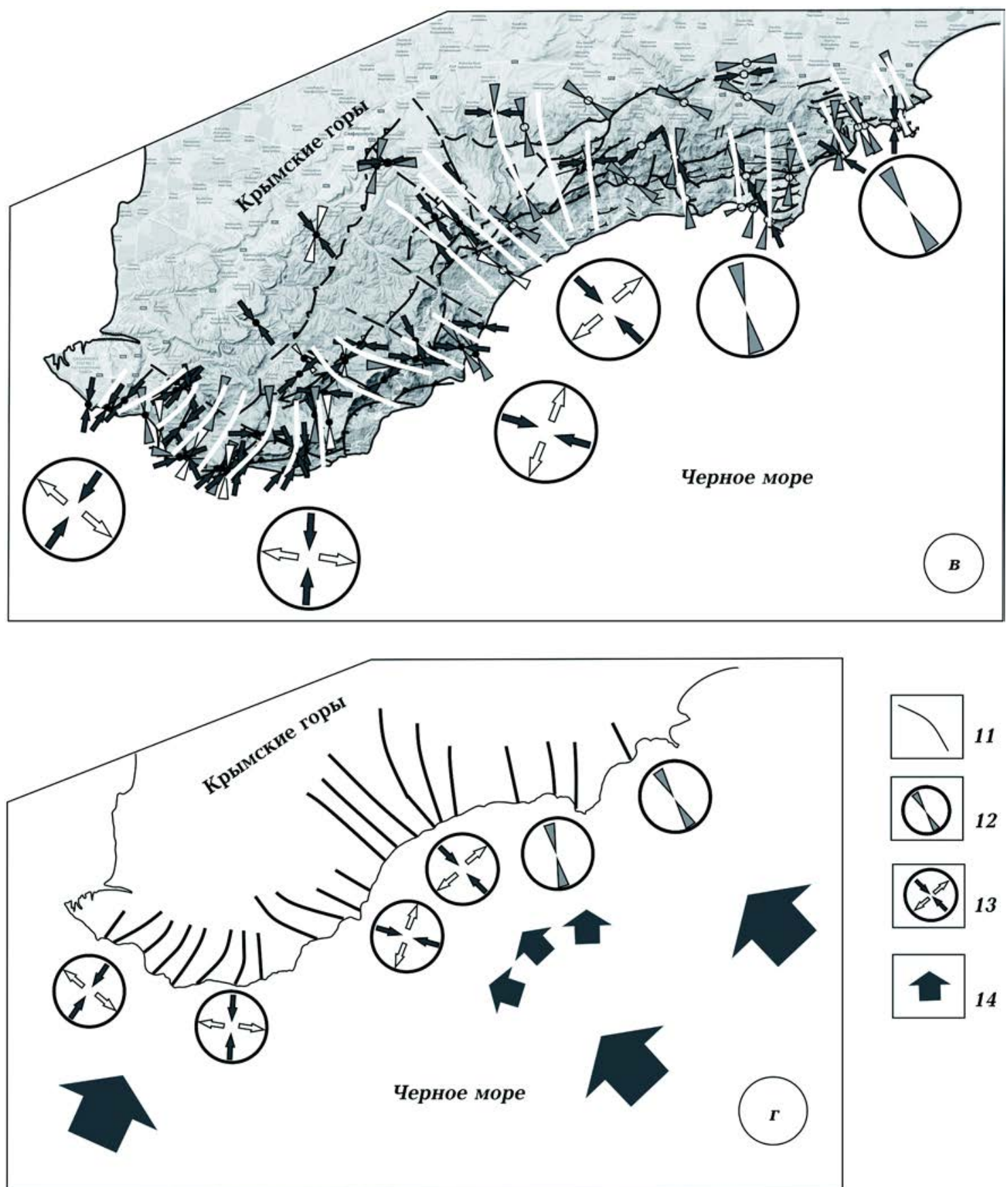

нарушения: 3 - надвиги, 4 - сбросы, 5 - сдвиги; $6-$ пункты наблюдений и их номера $(a-$ для ВГК, б - Аля ЗГК); ориентировка оси сжатия gля различных типов полей напряжений: 7 - покровного, 8 - взбросового, 9 - сдвигового; 10 - траектории сжатия; $\Gamma$ - схематическое изображение траекторий сжатия и направления внешнего воздействия: 11 - траектории сжатия; 12 - осредненное поле напряжений взбросового типа; 13 - осредненное поле напряжений сдвигового типа; 14 - направление внешних сил. 
А. МУРОВСКАЯ, Ж.-К. ИППОАИТ, Е. ШЕРЕМЕТ, Т. ЕГОРОВА

Т а б л и ц а 1. Пункты тектонофизических наблюдений и результаты определения полей напряжений Аля ВГК

\begin{tabular}{|c|c|c|c|c|c|c|}
\hline 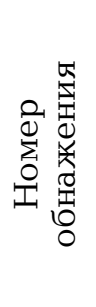 & Аолгота & Широта & $\begin{array}{c}\text { Литология, } \\
\text { возраст пород }\end{array}$ & 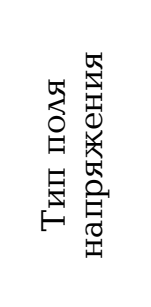 & 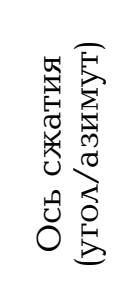 & 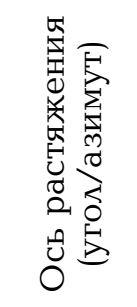 \\
\hline 1 & $34.34333^{\circ}$ & $44.87^{\circ}$ & Песчаник, $\mathrm{K}_{1}$ & САВиг & $11 / 149$ & $5 / 240$ \\
\hline 2 & $34^{\circ} 24^{\prime} 8.70^{\prime \prime}$ & $44^{\circ} 45^{\prime} 16.00^{\prime \prime}$ & Конгломерат, $\mathrm{J}_{3}$ & Сброс & $69 / 058$ & $20 / 214$ \\
\hline 3 & $34^{\circ} 27^{\prime} 32.70^{\prime \prime}$ & $44^{\circ} 48^{\prime} 25.56^{\prime \prime}$ & Конгломерат, $\mathbf{J}_{3}$ & Взброс & $02 / 200$ & $63 / 03$ \\
\hline 4 & $34.48333^{\circ}$ & $44.86015^{\circ}$ & Известняк, $\mathrm{J}_{3}$ & Взброс & $20 / 157$ & $61 / 348$ \\
\hline 5 & $34.415^{\circ}$ & $44.991^{\circ}$ & Известняк, $\mathrm{K}_{1}$ & $\begin{array}{c}\text { Взброс, } \\
\text { сдвиг }\end{array}$ & $\begin{array}{c}20 / 179 \\
0 / 83\end{array}$ & $\begin{array}{c}70 / 357 \\
5 / 173\end{array}$ \\
\hline 6 & $34.486667^{\circ}$ & $44.966667^{\circ}$ & Известняк, $\mathrm{K}_{1}$ & Взброс & $04 / 170$ & $63 / 071$ \\
\hline 7 & $34.6351^{\circ}$ & $44.901^{\circ}$ & $\begin{array}{c}\text { Конгломерат, } \mathrm{K}_{1} \\
\text { берриас }\end{array}$ & $\begin{array}{c}\text { Сброс, } \\
\text { взброс, } \\
\text { сдВиг }\end{array}$ & $\begin{array}{c}48 / 216 \\
07 / 344 \\
20 / 85\end{array}$ & $\begin{array}{l}07 / 118 \\
43 / 076 \\
12 / 179\end{array}$ \\
\hline 9 & $34.634^{\circ}$ & $44.911667^{\circ}$ & Флиш, $\mathrm{K}_{1}$ берриас & Сброс & $75 / 340$ & $14 / 149$ \\
\hline 11 & $34.634^{\circ}$ & $45.0101^{\circ}$ & Известняк, $\mathrm{K}_{1}$ & Взброс & $21 / 296$ & $57 / 170$ \\
\hline 12 & $34^{\circ} 43^{\prime} 44.7^{\prime \prime}$ & $44^{\circ} 52^{\prime} 33.09^{\prime \prime}$ & Флиш, $\mathrm{J}_{1}$ & $\begin{array}{l}\text { Сброс, } \\
\text { взброс }\end{array}$ & $\begin{array}{l}37 / 020 \\
24 / 293\end{array}$ & $\begin{array}{l}14 / 120 \\
52 / 168\end{array}$ \\
\hline 13 & $34.7093^{\circ}$ & $44.9363^{\circ}$ & Известняк, $\mathrm{K}_{1}$ & Сброс & $86 / 90$ & $03 / 315$ \\
\hline 14 & $34.75737^{\circ}$ & $44.93475^{\circ}$ & Флиш, $\mathrm{K}_{1}$ & САВиг & $17 / 47$ & $9 / 314$ \\
\hline 15 & $34^{\circ} 51^{\prime} 24.09^{\prime \prime}$ & $45^{\circ} 0^{\prime} 10.86^{\prime \prime}$ & Известняк, $\mathrm{E}_{1}$ & Взброс & $23 / 302$ & $67 / 108$ \\
\hline 16 & $34.835467^{\circ}$ & $44.9175^{\circ}$ & Флиш, $\mathrm{J}_{1}$ & $\begin{array}{l}\text { Взброс, } \\
\text { сдВиг }\end{array}$ & $\begin{array}{l}0 / 002 \\
2 / 342\end{array}$ & $\begin{array}{c}46 / 101 \\
3 / 72\end{array}$ \\
\hline 17 & $34^{\circ} 51^{\prime} 44.464^{\prime \prime}$ & $4^{\circ} 50^{\prime} 56.27^{\prime \prime}$ & Конгломерат, $\mathbf{J}_{2}$ & $\begin{array}{l}\text { Сброс, } \\
\text { взброс }\end{array}$ & $\begin{array}{l}72 / 193 \\
10 / 175\end{array}$ & $\begin{array}{c}07 / 082 \\
39 / 77\end{array}$ \\
\hline 18 & $34.90055^{\circ}$ & $44.82065^{\circ}$ & Известняк, $\mathrm{J}_{3}$ & Сброс & $59 / 057$ & $09 / 162$ \\
\hline 20 & $35.000633^{\circ}$ & $44.886433^{\circ}$ & Конгломерат, $\mathbf{J}_{3}$ & Взброс & $7 / 345$ & $38 / 244$ \\
\hline
\end{tabular}


Окончание табл. 1

\begin{tabular}{|c|c|c|c|c|c|c|}
\hline 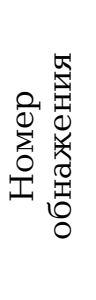 & Аолгота & Широта & $\begin{array}{c}\text { Литология, } \\
\text { возраст пород }\end{array}$ & 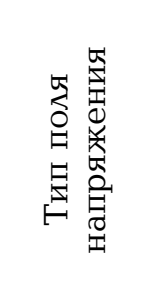 & 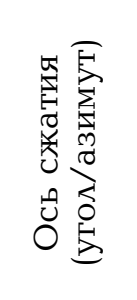 & 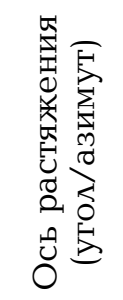 \\
\hline 21 & $34^{\circ} 58^{\prime} 52.94^{\prime \prime}$ & $44^{\circ} 53^{\prime} 33.88^{\prime \prime}$ & Известняк, $\mathrm{J}_{3}$ & САВиг & $10 / 343$ & $10 / 251$ \\
\hline 23 & $35.005383^{\circ}$ & $45.0162^{\circ}$ & Известняк, $\mathbf{J}_{3}$ & $\begin{array}{l}\text { Сброс, } \\
\text { взброс }\end{array}$ & $\begin{array}{c}72 / 104 \\
4 / 100\end{array}$ & $\begin{array}{l}08 / 348 \\
85 / 315\end{array}$ \\
\hline 24 & $35^{\circ} 0^{\prime} 1.76^{\prime \prime}$ & $45^{\circ} 3^{\prime} 8.97^{\prime \prime}$ & Конгломерат, $\mathbf{J}_{3}$ & САВиг & $14 / 77$ & $11 / 170$ \\
\hline 25 & $35.005983^{\circ}$ & $45.073017^{\circ}$ & Конгломерат, J 3 & $\begin{array}{c}\text { Взброс, } \\
\text { сдвиг }\end{array}$ & $2 / 77$ & $62 / 171$ \\
\hline 26 & $35^{\circ} 1^{\prime} 7.85^{\prime \prime}$ & $44^{\circ} 49^{\prime} 58.28^{\prime \prime}$ & Конгломерат, $\mathbf{J}_{2}$ & Взброс & $16 / 9$ & $40 / 123$ \\
\hline 27 & $34^{\circ} 59^{\prime} 18.07^{\prime \prime}$ & $44^{\circ} 50^{\prime} 2.85^{\prime \prime}$ & Известняк, $\mathbf{J}_{3}$ & $\begin{array}{l}\text { Сброс } \\
\text { взброс }\end{array}$ & $\begin{array}{c}36 / 158 \\
6 / 231\end{array}$ & $\begin{array}{l}09 / 355 \\
42 / 130\end{array}$ \\
\hline 31 & $35^{\circ} 3^{\prime} 2.89^{\prime \prime}$ & $44^{\circ} 48^{\prime} 33.73^{\prime \prime}$ & Флиш, $\mathbf{J}_{1}$ & $\begin{array}{c}\text { Взброс, } \\
\text { сАВиг }\end{array}$ & $\begin{array}{l}12 / 26 \\
4 / 345\end{array}$ & $\begin{array}{c}20 / 285 \\
2 / 75\end{array}$ \\
\hline 33 & $35.09925^{\circ}$ & $44.889250^{\circ}$ & Известняк, $\mathrm{J}_{3}$ & Взброс & $14 / 6$ & $52 / 258$ \\
\hline 34 & $35^{\circ} 13^{\prime} 21.13^{\prime \prime}$ & $44^{\circ} 55^{\prime} 5.63^{\prime \prime}$ & Вулканит, $\mathrm{K}_{1}$ & САВиг & $29 / 108$ & $22 / 21$ \\
\hline 35 & $35^{\circ} 13^{\prime} 6.69^{\prime \prime}$ & $44^{\circ} 56^{\prime} 37.11^{\prime \prime}$ & Известняк, $\mathrm{J}_{3}$ & Взброс & $1 / 179$ & $89 / 359$ \\
\hline 36 & $35.211483^{\circ}$ & $44.968417^{\circ}$ & Известняк, $\mathrm{J}_{3}$ & Взброс & $5 / 318$ & $81 / 197$ \\
\hline 37 & $35.264533^{\circ}$ & $44.966500^{\circ}$ & Флиш, $\mathbf{J}_{2}$ & $\begin{array}{l}\text { Сброс, } \\
\text { взброс }\end{array}$ & $\begin{array}{l}74 / 260 \\
15 / 162\end{array}$ & $\begin{array}{l}16 / 093 \\
48 / 054\end{array}$ \\
\hline 38 & $35.278133^{\circ}$ & $44.969050^{\circ}$ & Флиш, $\mathrm{J}_{2}$ & Взброс & $17 / 338$ & $63 / 105$ \\
\hline 42 & $35.349117^{\circ}$ & $44.969333^{\circ}$ & Конгломерат, $\mathbf{J}_{2}$ & САВиг & $9 / 2$ & 8/94 \\
\hline 43 & $35.360517^{\circ}$ & $44.990917^{\circ}$ & Флиш, $\mathrm{J}_{2}$ & Взброс & $13 / 328$ & $54 / 76$ \\
\hline 44 & $35^{\circ} 21^{\prime} 15.64^{\prime \prime}$ & $45^{\circ} 2^{\prime} 35.44^{\prime \prime}$ & Мергель, E2 & Взброс & $7 / 328$ & $79 / 98$ \\
\hline 45 & $36^{\circ} 29^{\prime} 32.79^{\prime \prime}$ & $45^{\circ} 19^{\prime} 2.22^{\prime \prime}$ & Известняк, $\mathrm{N}_{1}$ & Покров & $49 / 184$ & $41 / 360$ \\
\hline 46 & $34^{\circ} 26^{\prime} 42.63^{\prime \prime}$ & $44^{\circ} 44^{\prime} 2.93^{\prime \prime}$ & Конгломерат, $\mathbf{J}_{3}$ & Покров & $35 / 264$ & $53 / 60$ \\
\hline
\end{tabular}


А. МУРОВСКАЯ, Ж.-К. ИППОАИТ, Е. ШЕРЕМЕТ, Т. ЕГОРОВА

Т а б л и ц 2. Пункты тектонофизических наблюдений и результаты определения полей напряжений Аля ЗГК

\begin{tabular}{|c|c|c|c|c|c|c|}
\hline 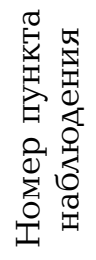 & Аолгота & Широта & $\begin{array}{c}\text { Аитология, } \\
\text { возраст пород }\end{array}$ & Тип поля & 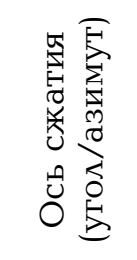 & 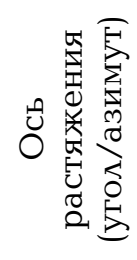 \\
\hline 1 & $33^{\circ} 28^{\prime} 54^{\prime \prime}$ & $44^{\circ} 30^{\prime} 31^{\prime \prime}$ & Известняк, $\mathrm{N}_{1}$ & САвиг & $37 / 18$ & $13 / 278$ \\
\hline 2 & $33^{\circ} 31^{\prime} 28^{\prime \prime}$ & $44^{\circ} 30^{\prime} 11^{\prime \prime}$ & Известняк, $\mathrm{J}_{3}$ & САвиг & $17 / 216$ & $29 / 117$ \\
\hline 3 & $44^{\circ} 31^{\prime} 11^{\prime \prime}$ & $33^{\circ} 33^{\prime \prime} 53^{\prime \prime}$ & Известняк, $\mathbf{J}_{3}$ & $\begin{array}{l}\text { Сброс, } \\
\text { сАВиг }\end{array}$ & $\begin{array}{c}74 / 293 \\
14 / 37\end{array}$ & $\begin{array}{l}14 / 148 \\
27 / 300\end{array}$ \\
\hline 4 & $33^{\circ} 35^{\prime} 43^{\prime \prime}$ & $44^{\circ} 29^{\prime} 48^{\prime \prime}$ & Известняк, J3 & Сброс & $58 / 216$ & $08 / 318$ \\
\hline 5 & $33^{\circ} 36^{\prime} 42^{\prime \prime}$ & $44^{\circ} 29^{\prime} 30^{\prime \prime}$ & Известняк, $\mathbf{J}_{3}$ & Взброс & $9 / 170$ & $71 / 275$ \\
\hline 7 & $33^{\circ} 40^{\prime} 54^{\prime \prime}$ & $44^{\circ} 32^{\prime} 48^{\prime \prime}$ & Мергель, К 2 & САВиг & $31 / 242$ & $1 / 333$ \\
\hline 8 & $33^{\circ} 40^{\prime} 58^{\prime \prime}$ & $44^{\circ} 31^{\prime} 56^{\prime \prime}$ & Известняк, $\mathrm{J}_{3}$ & САВиг & $0 / 252$ & $21 / 342$ \\
\hline 9 & $33^{\circ} 42^{\prime} 1^{\prime \prime}$ & $44^{\circ} 32^{\prime} 21^{\prime \prime}$ & Известняк, $\mathrm{J}_{3}$ & САвиг & $4 / 46$ & $8 / 316$ \\
\hline 10 & $33^{\circ} 43^{\prime} 00^{\prime \prime}$ & $44^{\circ} 31^{\prime} 48^{\prime \prime}$ & Известняк, $\mathrm{K}_{1}$ & САВиг & $5 / 343$ & $4 / 73$ \\
\hline 10 в & $44^{\circ} 30^{\prime} 60^{\prime \prime}$ & $33^{\circ} 46^{\prime} 10^{\prime \prime}$ & Известняк, $\mathrm{K}_{1}$ & Взброс & $30 / 28$ & $37 / 143$ \\
\hline 11 & $33^{\circ} 38^{\prime} 50^{\prime \prime}$ & $44^{\circ} 28^{\prime} 17^{\prime \prime}$ & Конгломерат, J 3 & Покров & $43 / 169$ & $41 / 6$ \\
\hline 12 & $33^{\circ} 41^{\prime} 36^{\prime \prime}$ & $44^{\circ} 28^{\prime} 46^{\prime \prime}$ & Известняк, $\mathrm{J}_{3}$ & Сброс & $68 / 22$ & $22 / 200$ \\
\hline 13 & $33^{\circ} 42^{\prime} 0.00^{\prime \prime}$ & $44^{\circ} 28^{\prime} 36^{\prime \prime}$ & Известняк, $\mathrm{J}_{3}$ & САВиг & $2 / 43$ & $11 / 313$ \\
\hline 14 & $33^{\circ} 41^{\prime} 602^{\prime \prime}$ & $44^{\circ} 28^{\prime \prime} 757^{\prime \prime}$ & Известняк, $\mathrm{J}_{3}$ & Сброс & $78 / 170$ & $11 / 005$ \\
\hline 15 & $33^{\circ} 41^{\prime} 34^{\prime \prime}$ & $44^{\circ} 25^{\prime} 24^{\prime \prime}$ & Известняк, $\mathbf{J}_{3}$ & $\begin{array}{c}\text { Взброс, } \\
\text { сдвиг }\end{array}$ & $\begin{array}{c}0 / 283 \\
1 / 81\end{array}$ & $\begin{array}{c}85 / 16 \\
27 / 350\end{array}$ \\
\hline 16 & $33^{\circ} 42^{\prime} 28^{\prime \prime}$ & $44^{\circ} 25^{\prime} 43^{\prime \prime}$ & Известняк, $\mathrm{J}_{3}$ & $\begin{array}{c}\text { Сброс, } \\
\text { сАвиг }\end{array}$ & $\begin{array}{c}49 / 265 \\
7 / 136\end{array}$ & $\begin{array}{c}03 / 171 \\
17 / 44\end{array}$ \\
\hline 17 & $33^{\circ} 43^{\prime} 09^{\prime \prime}$ & $44^{\circ} 25^{\prime} 49^{\prime \prime}$ & Известняк, $\mathrm{J}_{3}$ & Покров & $30 / 66$ & $49 / 198$ \\
\hline 18 & $33^{\circ} 46^{\prime} 48^{\prime \prime}$ & $44^{\circ} 24^{\prime} 18^{\prime \prime}$ & Известняк, $\mathrm{J}_{3}$ & $\begin{array}{l}\text { Сброс, } \\
\text { СдВиг }\end{array}$ & $\begin{array}{c}79 / 201 \\
3 / 46\end{array}$ & $\begin{array}{l}11 / 025 \\
7 / 136\end{array}$ \\
\hline
\end{tabular}


Прояолжение табл. 2

\begin{tabular}{|c|c|c|c|c|c|c|}
\hline 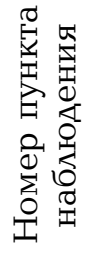 & Аолгота & Широта & $\begin{array}{c}\text { Литология, } \\
\text { возраст пород }\end{array}$ & Тип поля & 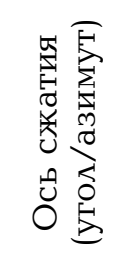 & 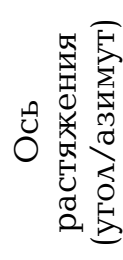 \\
\hline 19 & $33^{\circ} 47^{\prime} 14^{\prime \prime}$ & $44^{\circ} 24^{\prime} 24^{\prime \prime}$ & Известняк, $\mathrm{J}_{3}$ & Сброс & $68 / 125$ & $02 / 032$ \\
\hline 20 & $33^{\circ} 47^{\prime} 39^{\prime \prime}$ & $44^{\circ} 24^{\prime} 21^{\prime \prime}$ & Известняк, $\mathrm{J}_{3}$ & Взброс & $7 / 32$ & $77 / 272$ \\
\hline 21 & $33^{\circ} 47^{\prime} 53^{\prime \prime}$ & $44^{\circ} 24^{\prime} 03^{\prime \prime}$ & Вулканит, $\mathbf{J}_{2}$ & $\begin{array}{c}\text { Взброс, } \\
\text { сдВиг }\end{array}$ & $\begin{array}{c}31 / 13 \\
35 / 244\end{array}$ & $\begin{array}{l}49 / 147 \\
3 / 336\end{array}$ \\
\hline 22 & $33^{\circ} 49^{\prime} 39^{\prime \prime}$ & $44^{\circ} 24^{\prime \prime} 22^{\prime \prime}$ & Вулканит, $\mathbf{J}_{2}$ & САВиг & $29 / 15$ & $16 / 275$ \\
\hline 23 & $33^{\circ} 51^{\prime} 12^{\prime \prime}$ & $44^{\circ} 25^{\prime} 09^{\prime \prime}$ & Известняк, $\mathbf{J}_{3}$ & $\begin{array}{l}\text { Сброс, } \\
\text { сдвиг }\end{array}$ & $\begin{array}{c}60 / 095 \\
0 / 61\end{array}$ & $\begin{array}{l}09 / 201 \\
7 / 151\end{array}$ \\
\hline 24 & $33^{\circ} 52^{\prime} 04^{\prime \prime}$ & $44^{\circ} 27^{\prime} 47^{\prime \prime}$ & Известняк, $\mathbf{J}_{3}$ & $\begin{array}{l}\text { Сброс, } \\
\text { сАвиг }\end{array}$ & $\begin{array}{l}77 / 070 \\
21 / 276\end{array}$ & $\begin{array}{l}08 / 196 \\
13 / 181\end{array}$ \\
\hline 25 & 33,895367 & 44,494067 & Известняк, $\mathrm{J}_{3}$ & Взброс & $0 / 180$ & $89 / 91$ \\
\hline 26 & $33^{\circ} 55^{\prime} 57^{\prime \prime}$ & $44^{\circ} 24^{\prime} 12^{\prime \prime}$ & Флиш, $\mathrm{J}_{2}$ & САВиг & $12 / 222$ & $36 / 321$ \\
\hline 27 & $33^{\circ} 57^{\prime} 18^{\prime \prime}$ & $44^{\circ} 24^{\prime} 48^{\prime \prime}$ & Известняк, $\mathrm{J}_{3}$ & САВиг & $23 / 212$ & $5 / 304$ \\
\hline 28 & $33^{\circ} 57^{\prime} 15^{\prime \prime}$ & $44^{\circ} 26^{\prime} 05^{\prime \prime}$ & Известняк, $\mathrm{J}_{3}$ & САвиг & $1 / 323$ & $11 / 54$ \\
\hline 29 & $33^{\circ} 58^{\prime} 41^{\prime \prime}$ & $44^{\circ} 26^{\prime} 14^{\prime \prime}$ & Известняк, $\mathrm{J}_{3}$ & САВиг & $20 / 179$ & $6 / 271$ \\
\hline 30 & $33^{\circ} 57^{\prime} 51^{\prime \prime}$ & $44^{\circ} 33^{\prime} 34^{\prime \prime}$ & Аиабаз, $\mathrm{J}_{2}$ & САВиг & $5 / 46$ & $12 / 315$ \\
\hline 31 & $33^{\circ} 58^{\prime} 30^{\prime \prime}$ & $44^{\circ} 35^{\prime} 06^{\prime \prime}$ & Флиш, $\mathbf{J}_{2}$ & Покров & $43 / 142$ & $42 / 332$ \\
\hline 32 & $34^{\circ} 00^{\prime} 00^{\prime \prime}$ & $44^{\circ} 29^{\prime} 36^{\prime \prime}$ & Известняк, $\mathbf{J}_{3}$ & $\begin{array}{c}\text { Взброс, } \\
\text { сдвиг }\end{array}$ & $\begin{array}{l}6 / 359 \\
4 / 338\end{array}$ & $\begin{array}{c}77 / 245 \\
4 / 248\end{array}$ \\
\hline 33 & $34^{\circ} 01^{\prime} 18^{\prime \prime}$ & $44^{\circ} 33^{\prime} 34^{\prime \prime}$ & Известняк, $\mathrm{J}_{3}$ & САВиг & $10 / 278$ & $8 / 10$ \\
\hline 34 & $34^{\circ} 01^{\prime} 55^{\prime \prime}$ & $44^{\circ} 28^{\prime} 56^{\prime \prime}$ & Известняк, J 3 & Покров & $34 / 335$ & $49 / 194$ \\
\hline 35 & $34^{\circ} 04^{\prime} 05^{\prime \prime}$ & $44^{\circ} 34^{\prime} 51^{\prime \prime}$ & Аиабаз, $\mathbf{J}_{2}$ & $\begin{array}{c}\text { Сброс, } \\
\text { покров, } \\
\text { САВиг }\end{array}$ & $\begin{array}{l}86 / 076 \\
36 / 159 \\
11 / 213\end{array}$ & $\begin{array}{c}03 / 289 \\
46 / 19 \\
22 / 308\end{array}$ \\
\hline 36 & $34^{\circ} 06^{\prime} 01^{\prime \prime}$ & $44^{\circ} 36^{\prime} 30^{\prime \prime}$ & Флиш, $\mathrm{T}_{3}-\mathrm{J}_{1}$ & $\begin{array}{c}\text { Сброс, } \\
\text { сАВиг }\end{array}$ & $\begin{array}{c}73 / 052 \\
8 / 269\end{array}$ & $\begin{array}{l}04 / 155 \\
18 / 176\end{array}$ \\
\hline
\end{tabular}


А. МУРОВСКАЯ, Ж.-К. ИППОЛИТ, Е. ШЕРЕМЕТ, Т. ЕГОРОВА

Окончание табл. 2

\begin{tabular}{|c|c|c|c|c|c|c|}
\hline 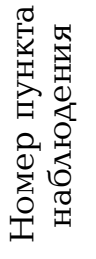 & Аолгота & Широта & $\begin{array}{c}\text { Литология, } \\
\text { возраст пород }\end{array}$ & Тип поля & 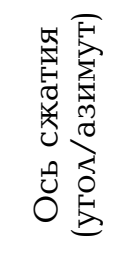 & 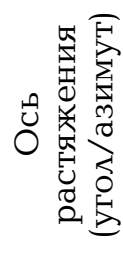 \\
\hline 37 & $34^{\circ} 08^{\prime} 12^{\prime \prime}$ & $44^{\circ} 30^{\prime} 42^{\prime \prime}$ & $\begin{array}{c}\text { Глинистый } \\
\text { известняк, } \mathrm{J}_{3}\end{array}$ & Сброс & $83 / 278$ & $03 / 165$ \\
\hline 38 & $34^{\circ} 10^{\prime} 37^{\prime \prime}$ & $44^{\circ} 31^{\prime} 40^{\prime \prime}$ & $\begin{array}{c}\text { Слоистый } \\
\text { известняк, } \mathrm{J}_{3}\end{array}$ & Сброс & $85 / 171$ & $03 / 309$ \\
\hline 39 & $34^{\circ} 09^{\prime} 26^{\prime \prime}$ & $44^{\circ} 33^{\prime} 00^{\prime \prime}$ & $\begin{array}{c}\text { Слоистый } \\
\text { известняк, } \mathrm{J}_{3}\end{array}$ & САВиг & $7 / 39$ & $1 / 309$ \\
\hline 40 & $34^{\circ} 10^{\prime} 58^{\prime \prime}$ & $44^{\circ} 34^{\prime} 17^{\prime \prime}$ & $\begin{array}{c}\text { Слоистый } \\
\text { известняк, } \mathrm{J}_{3}\end{array}$ & Взброс & $27 / 286$ & $56 / 148$ \\
\hline 41 & $34^{\circ} 13^{\prime} 44^{\prime \prime}$ & $44^{\circ} 35^{\prime} 02^{\prime \prime}$ & Известняк, J 3 & $\begin{array}{l}\text { Сброс, } \\
\text { сдвиг }\end{array}$ & $\begin{array}{c}56 / 087 \\
24 / 99 \\
\end{array}$ & $\begin{array}{c}16 / 202 \\
5 / 191 \\
\end{array}$ \\
\hline 42 & $34^{\circ} 13^{\prime} 40^{\prime \prime}$ & $44^{\circ} 36^{\prime} 49^{\prime \prime}$ & Известняк, J 3 & $\begin{array}{c}\text { Взброс, } \\
\text { сдВиг }\end{array}$ & $\begin{array}{l}15 / 137 \\
31 / 150\end{array}$ & $\begin{array}{l}69 / 272 \\
6 / 244\end{array}$ \\
\hline 43 & $34^{\circ} 20^{\prime} 05^{\prime \prime}$ & $44^{\circ} 36^{\prime} 12^{\prime \prime}$ & Аиорит, $\mathrm{J}_{2}$ & САВиг & $0 / 259$ & $8 / 169$ \\
\hline 44 & $34^{\circ} 14^{\prime} 37^{\prime \prime}$ & $44^{\circ} 38^{\prime} 35^{\prime \prime}$ & Известняк, $\mathrm{J}_{3}$ & Сброс & $41 / 100$ & $05 / 194$ \\
\hline 45 & $34^{\circ} 22^{\prime} 02^{\prime \prime}$ & $44^{\circ} 35^{\prime} 28^{\prime \prime}$ & Аиабаз, $\mathbf{J}_{2}$ & Взброс & $27 / 337$ & $63 / 158$ \\
\hline 46 & $34^{\circ} 22^{\prime} 45^{\prime \prime}$ & $44^{\circ} 38^{\prime} 14^{\prime \prime}$ & Аиорит, $\mathbf{J}_{2}$ & $\begin{array}{c}\text { Взброс, } \\
\text { сдВиг }\end{array}$ & $\begin{array}{c}7 / 92 \\
15 / 98\end{array}$ & $\begin{array}{l}40 / 355 \\
23 / 2\end{array}$ \\
\hline 47 & $34^{\circ} 19^{\prime} 57^{\prime \prime}$ & $44^{\circ} 45^{\prime} 14^{\prime \prime}$ & Флиш, $\mathrm{T}_{3}-\mathrm{J}_{1}$ & Сброс & $65 / 333$ & $10 / 085$ \\
\hline 48 & $34^{\circ} 20^{\prime} 09^{\prime \prime}$ & $44^{\circ} 48^{\prime} 03^{\prime \prime}$ & Флиш, $\mathrm{T}_{3}-\mathrm{J}_{1}$ & Покров & $41 / 332$ & $32 / 184$ \\
\hline 49 & $34^{\circ} 16^{\prime} 15^{\prime \prime}$ & $44^{\circ} 46^{\prime} 50^{\prime \prime}$ & Известняк, $\mathrm{J}_{3}$ & САвиг & $19 / 148$ & $11 / 58$ \\
\hline 50 & $34^{\circ} 16^{\prime} 35^{\prime \prime}$ & $44^{\circ} 49^{\prime} 08^{\prime \prime}$ & Известняк, J 3 & САВиг & $1 / 136$ & $6 / 226$ \\
\hline 52 & $34^{\circ} 08^{\prime} 33^{\prime \prime}$ & $44^{\circ} 53^{\prime} 53^{\prime \prime}$ & Аиабаз, $\mathrm{J}_{2}$ & Взброс & $26 / 5$ & $59 / 148$ \\
\hline 54 & $34^{\circ} 00^{\prime} 13^{\prime \prime}$ & $44^{\circ} 47^{\prime} 8^{\prime \prime}$ & Андезит, $\mathbf{J}_{2}$ & $\begin{array}{c}\text { Покров, } \\
\text { сдвиг }\end{array}$ & $\begin{array}{c}42 / 18 \\
19 / 312 \\
\end{array}$ & $\begin{array}{c}47 / 180 \\
3 / 43 \\
\end{array}$ \\
\hline 57 & $33^{\circ} 53^{\prime} 46^{\prime \prime}$ & $44^{\circ} 44^{\prime} 49^{\prime \prime}$ & Известняк, Е & САвиг & $12 / 304$ & $6 / 35$ \\
\hline 61 & $33^{\circ} 51^{\prime} 18^{\prime \prime}$ & $44^{\circ} 33^{\prime} 12^{\prime \prime}$ & Песчаник, K 1 & Сброс & $47 / 100$ & 03/007 \\
\hline 62 & $34.16935^{\circ}$ & 44.909267 & Аиабаз, $\mathbf{J}_{2}$ & Взброс, & $2 / 271$ & $64 / 4$ \\
\hline
\end{tabular}



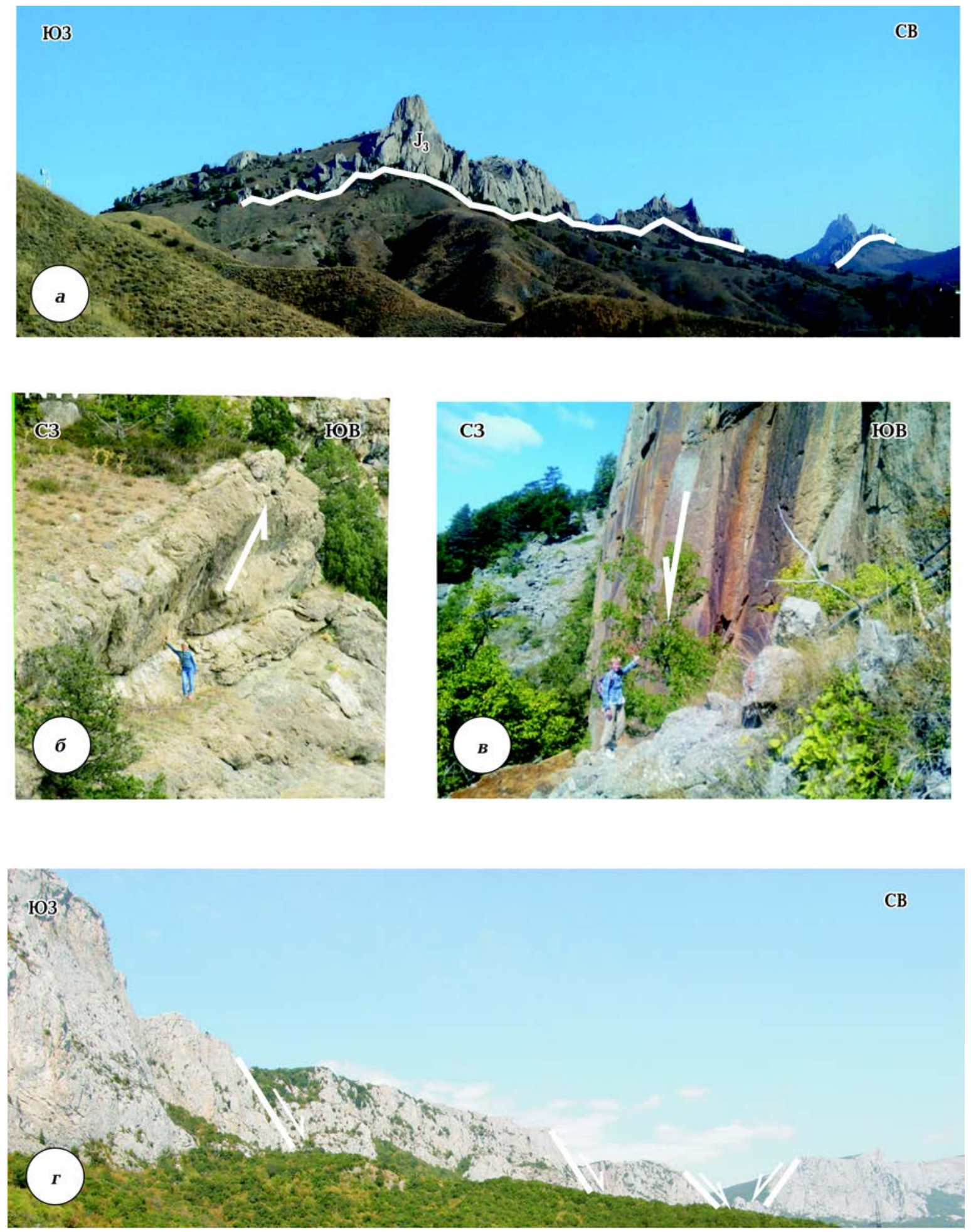

Рис. 4. Примеры структур сжатия и растяжения: $a$ - полоса выходов крутопадающих верхнеюрских известняков протягивается в широтном направлении и маркирует фронт надвига, северо-западная окраина пгт Курортное (крайний справа гребень — г. Сюрю-Кая (табл. 1, п. 35)); б — Балаклавский наАвиг на восточной окраине пгт Балаклава (табл. 2, п. 2) активировался по несогласному стратиграфическому контакту на этапе кайнозойского сжатия; в - сбросовый разлом на восточном склоне г. Южная Аемерджи (табл. 1, п. 2) ограничивает с запада раннемеловую Салгирскую депрессию; $\Gamma$ - верхнеюрская карбонатная платформа, нарушенная сбросовыми разрывами, активированными на этапе плиоценового воздымания ГК (вид со стороны пгт Берегово (табл. 2, п. 28, 29)). Стрелки показывают направление перемещения висячего крыла. 


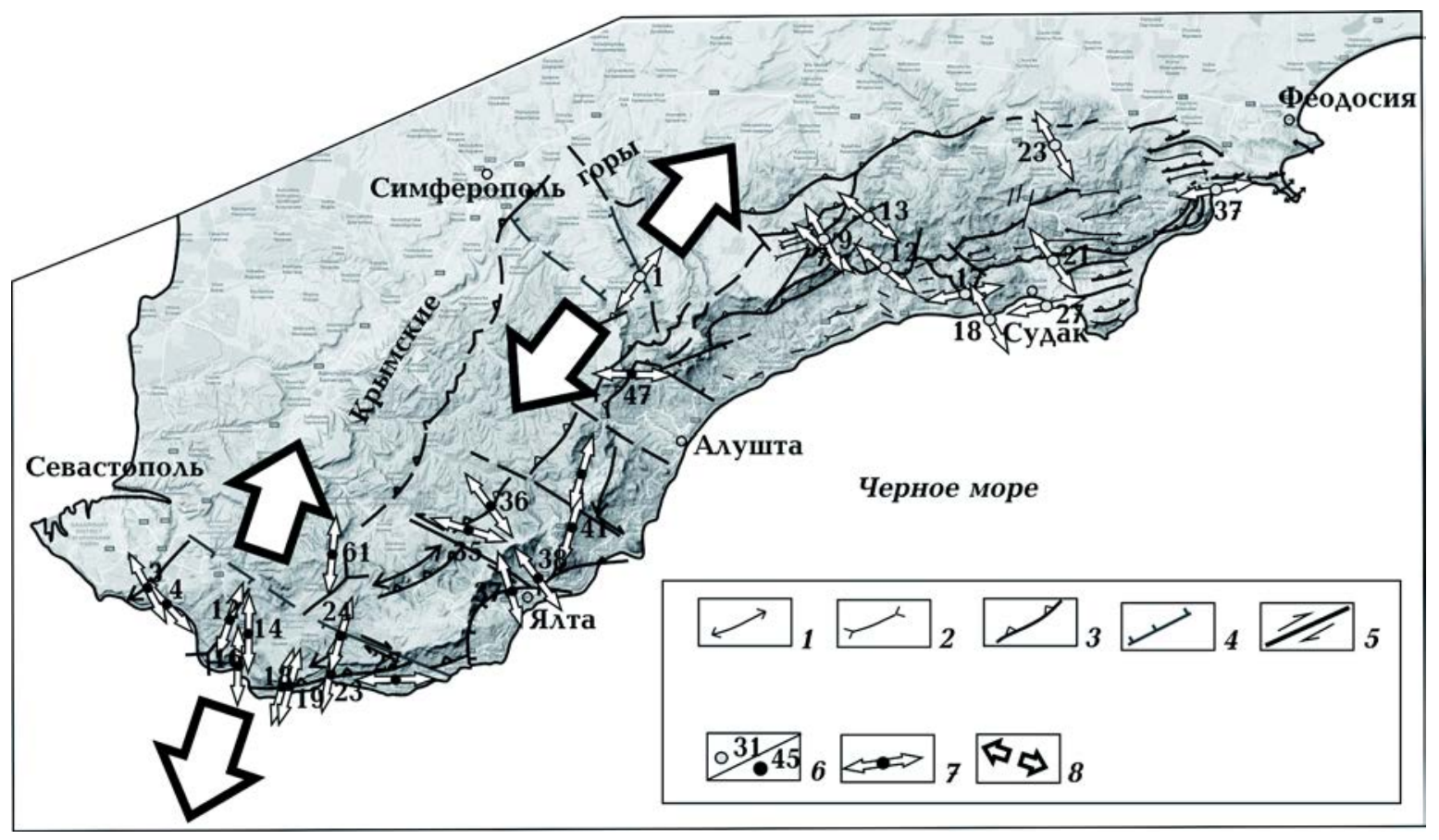

Рис. 5. Ориентировка осей растяжения для полей напряжений сбросового типа: $1-6$ см. на рис. $3 ; 7-$ ориентировка действующей оси растяжения для полей сбросового типа; 8 - ориентировка раннемелового растяжения определена для групп конседиментационных сбросовых нарушений.

ские-берриасовые известняки Айпетринской яйлы в ЗГК и отчетливо просматривается со стороны южного крутого склона (рис. 4, $г$, табл. 2, п. 28, 29).

В центральной части ГК были обнаружены крупные тектонические зеркала сбросового типа, ограничивающие Салгирскую эрозионно-тектоническую депрессию с востока и открывшееся в результате крупного обвала в районе поселка $\lambda$ чистое у западного подножья г. Южная Аемерджи (см. рис. 4, б, табл. 1, п. 2). Аля двух названных участков была восстановлена несколько различная ориентировка раннемелового растяжения: юго-юго-запал-северо-северо-восток в ЗГК и югозапад-северо-восток в центральной части ГК (рис. 5).

Обсуждение результатов. Геологическая эволюция ГК тесно связана с событиями, происходившими на южной окраине Восточно-Европейской платформы открытием и эволюцией Черноморского бассейна, а также инверсией его окраин и формированием окаймляющих горно- складчатых сооружений. Отпечатки этих процессов сохранились в той или иной мере в вещественноструктурных комплексах регионального масштаба и деформационных элементах мезоуровня (в пределах отдельных обнажений). При этом следы более древних событий "затерлись" более молодыми, будучи для них общим фоном, а следы последних событий сохранились более отчетливо. Поэтому будем рассматривать эволюцию полей напряжений с настоящего момента и Авигаться в обратном направлении - в глубину времен.

Сейсмичность в пределах КСЗ является индикатором современных тектонических процессов, которые продолжают этап кайнозойского сжатия. Большинство очагов сильных землетрясений КСЗ расположены в полосе между Южным берегом Крыма и подошвой континентального склона и свидетельствуют о том, что основной тектонический процесс происходит именно здесь, в зоне взаимодействия Скифской плиты и Черноморской мик- 
роплиты, а структуры северной окраины ЧМ и ГК взаимосвязаны единым геодинамическим процессом.

Как показано в работе [Гобаренко и др., 2016], сейсмичность в пределах КСЗ неравномерно распределяется по глубине и по простиранию зоны, а гипоцентры слабых землетрясений формируют отдельные скопления, среди которых: Севастопольский, Ялтинско-Алуштинский, Судакский и Керченско-Таманский кластеры [Гобаренко и др., 2016]. Это свидетельствует о существовании вещественно-структурно-кинематических неоднородностей в зоне коллизионного взаимодействия и реактивации древних субвертикальных и субгоризонтальных ослабленных зон в земной коре КСЗ.

Аля расшифровки характера и особенностей современного деформационного процесса в регионе привлечены механизмы очагов сильных землетрясений КСЗ. В Ялтинско-Алуштинской подзоне в месте максимального изгиба береговой линии и наиболее узкого шельфа механизмы трех землетрясений указывают на взбросовый тип деформаций и свидетельствуют о разрядке здесь напряжений сжатия в юговосточно-северо-западном и юго-западно-северо-восточном направлениях (см. рис. 2). Ава механизма взбросового типа, расположенные в месте максимального южного выступа КСЗ, также демонстрируют разрядку напряжений сжатия. Цепочка из пяти очагов с различными типами механизмов, прослеживающихся на юг по меридиану Ялта-Симферополь, очевидно, связана с активизацией древней тектонической зоны, которая, по мнению некоторых авторов [Гинтов, 2005; Гобаренко и др., 2016 и ссылки в них], разделяет ЗГК и ВГК.

Судакско-Феодосийский участок в целом характеризуется более низким уровнем сейсмичности по сравнению с Ялтинско-Алуштинским сектором. Здесь зафиксированы два сильных землетрясения с механизмами сбросового и покровного (или взбросо-сбросового) типов (см. рис. 2). Эти особенности свидетельствуют о меньшем объеме накапливаемой здесь упругой энергии, что может быть связано с реологическими особенностями сейсмогенерирующей среды.

Этап кайнозойского сжатия в ГК, обусловленный коллизионными процессами, начался в олигоцене [Finetti et al., 1988; Паталаха и Ар., 2003; Гончар, 2013, 2015; Nikishin et al., 2017] или в палеоцене [Sheremet et al., 2016b]. Как показывают наши тектонофизические и геолого-структурные наблюдения [Муровская и др., 2014; Sheremet et al., 2016a] и сейсмогеологические разрезы [Finetti et al., 1988; Nikishin et al., 2015a, b], на этапе сжатия на суше и шельфе инвертируются древние тектонические нарушения, связанные с этапом растяжения, а также формируется складчато-надвиговая структура в мощной толще олигоцен-плиоценовых осадков прогиба Сорокина.

Этап кайнозойского сжатия в ГК мы характеризуем траекториями сокращения, отражающими суммарный эффрект деформаций взбросового, покровного и сдвигового типов. В центральной части ГК (район Чатыр-Аага, Аемерджи, Караби) преобладают поля напряжений сАвигового типа с северо-западно-юго-восточной ориентировкой оси сжатия, что согласуется, например, с результатами геолого-структурных наблюдений для Аолгоруковской яйлы, состоящей из серии аллохтонных пластин северо-восточного простирания [Милеев и др., 1998].

Пространственное распределение типов полей напряжений по полевым тектонофизическим исследованиям свидетельствует об отличии СФЗ от западной и центральной частей ГК. В СФЗ преобладают поля напряжений взбросового типа с ориентировкой оси сжатия северюг или северо-северо-запад-юго-юго-восток, которые мы связываем с фазами складчатости и орогенеза в кайнозое-квартере. Ориентировка взбросовых полей напряжений согласуется с субширотным простиранием надвиговых структур в пределах ВГК (см. структурную карту [Sheremet et al., 2016a]). 
В геологическом строении и тектонической эволюции СФЗ существуют особенности, отмеченные большинством исследователей, например [Муратов, 1969; Nikishin et al., 2017; Юдин, 2011]. На тектонической схеме (см. рис. 2) к востоку от линии Судак-Старый Крым расположен Судакский синклинорий [ Муратов, 1969], который входит в состав СуАакского трога и простирается в северовосточном направлении до Феодосии [Nikishin et al., 2017]. Начиная со средней юры, в Судакском троге отмечаются более глубоководные фации, чем к западу от него, а осадконакопление в его пределах происходит непрерывно вплоть до эоцена [Nikishin et al., 2017]. В результате здесь была отложена мощная толща слоистых пластичных образований, деформированная, выведенная на земную поверхность и эродированная на этапе кайнозойского сжатия.

К западу от Алушты (район г. Кастель, Бабуган-яйлы, южный склон Качинского поднятия) и до м. Аю-Ааг тренд сжатия становится субширотным. Это соответствует области разворота северо-восточных структур ЗГК в меридиональном направлении, характерном для Салгирской депрессии и Чатыр-Аага. В работах [Гончар, 2013, 2015; Гинтов, 2005] дугообразный разворот структур ЗГК связан со структурами подворота при левосдвиговом перемещении по Салгиро-Октябрьскому разлому [Гончар, 2013, 2015]. Очевилно, на этапе кайнозойского сжатия зона субмеридионального разлома имела/имеет взбросовую компоненту, чем и объясняются субширотные направления наших траекторий сокращения, а также взбросовые составляющие в механизмах очагов вдоль ее продолжения в ЧМ.

В целом, в дугообразном секторе Южного берега Крыма от м. Меганом до м. АюАаг получено веерообразное распределение напряжений сжатия. Подобный рисунок траекторий был получен в работах [Паталаха и Ар., 2003; Гончар, 2015] при математическом моделировании методом конечных элементов в рамках коллизионной модели и объясняется инденторным воз- действием Восточно-Черноморской впадины на южную окраину Скифской плиты.

Юго-западная часть ГК характеризуется юго-западным - северо-восточным направлением сжатия. Следует отметить, что такой, несколько неожиданный тренд отмечался некоторыми авторами и раньше [Гинтов, 2005; Вольфман, 2015 и ссылки в них]. Аля его объяснения нет однозначного ответа. Взбросовые режимы югозападного сжатия, возможно, возникли в результате активации древних сбросов на кайнозойском этапе. Сдвиговые режимы могут быть связаны с кинематикой Западно-Черноморского правого сдвига, ограничивающего с запада южно-крымский надвиговый фронт. Аналогичное юго-запалное направление сжатия получено Ж.-К. Ипполитом для Центральных Понтид и связывается автором с коллизией Тавро-Анатолийского блока с Понтидами [Hippolyte et al., 2010, 2016].

Этап растяжения в ЗГК начинается в валанжин-барремское время и достигает максимальной интенсивности в аптское. Он подтверждается конседиментационным сбросообразованием и формированием олистостромовых комплексов на протяжении практически всего раннего мела.

Нашим исследованием выявлен ряд молодых сбросовых зеркал и соответствующих деформационных режимов растяжения. Эти сбросовые разрывы мы связываем с влиянием гравитации и активизацией более древних разломов при воздымании в плиоцене ГК [Муровская, 2012; Муровская и др., 2014].

Выводы. В данном исследовании рассмотрена эволюция ГК и прилегающей части ЧМ во временном интервале от раннего мела до настоящего времени. Региональная геологическая ситуация в Циркум-Черноморском регионе и наши геолого-структурные наблюдения позволили выделить два генерализованных этапа в эволюции изученной территории: мелового растяжения и кайнозойского сжатия, продолжающегося и в настоящее время. Тектонофизические наблюдения и анализ механизмов землетрясений позволили уточ- 
нить ориентировку растяжения и сжатия, а также особенности пространственного распределения деформации.

Раннемеловое растяжение проявилось в деструкции верхнеюрской карбонатной платформы по системе сбросовых нарушений. Было получено направление растяжения северо-северо-восток-юго-югозапад для юго-западной части ГК и направление растяжения северо-востокюго-запад для его центральной части. Возможно, поля напряжений сбросового типа и соответствующие структуры растяжения связаны с фазой рифтинга и раскрытия ЧМ.

С этапом кайнозойского сжатия авторы связывают поля напряжения взбросового, покровного и сАвигового типов. Аля Судакско-Феодосийского района характерны поля напряжений взбросового типа, а для центральной и западной частей ГК - сАвигового. При этом траектории сжатия образуют веерообразный рисунок и изменяют свое направление от североюжного в Судакской зоне до северо-западно-юго-восточного в центральной зоне, затем до восточно-западного и, наконец, приобретают северо-восточно-югозападную ориентировку в самой западной части ГК. Веерообразный рисунок траекторий сжатия связывается с Аугообразной формой надвигового фронта.

Обобщение механизмов очагов 32 сильных землетрясений в пределах северной окраины ЧМ за 1927-2016 гг. показало преобладание взбросового и покровного дефрормационных режимов. Ориентировки осей сжатия в очагах отноительно ориентировки КСЗ свидетельствуют о том, что современный тектонический процесс

\section{Список литературы}

Афанасенков А.П., Никишин А.М., Обухов А.Н. Геологическое строение и углеводородный потенциал Восточно-Черноморского региона. Мо-сква: Научный мир, 2007. 172 с.

Балакина А.М., Ввеgенская А.В., Голубева И.В., происходит преимущественно в условиях сжатия и транспрессии.

Анализ 13 механизмов очагов землетрясений, расположенных вдоль побережья Крыма в пределах Южно-Крымского надвигового фронта, показывает преобладание взбросовых деформаций в центральной части КСЗ и сдвиговых деформаций на ее западном завершении. Рассчитанный средний механизм относится к взбросовому типу при ориентировке оси сжатия в направлении северо-запад-юговосток и показывает генерализованное направление сокращения, при этом перемещения по отдельным нодальным плоскостям реализуются в различных направлениях, что связано с изменением во времени и пространстве полей напряжений второго порядка.

С точки зрения деформационных режимов - сжатия и транспрессии и с учетом направления укорочения северо-запад- юго-восток современный тектонический процесс в пределах КСЗ является продолжением этапа кайнозойского сжатия и отражает подАвиг субокеанической коры ВЧМП под континентальную кору Скифской плиты.

Благодарности. Полевые тектонофизические работы 2012 г. выполнены в рамках программы Darius 2012 благодаря проф. C. Morhange в рамках проекта AMIDEXGEOMED Аикс-Марсельского Университета. Обобщение и переинтерпретация полевых материалов 1991-2012 гг. выполнены в рамках IRG проекта по наукам о земле Южного Кавказа 2012-2017 гг. Авторы выражают благодарность О. Гинтову, Ю. Вольфману, Е. Колесниковой за предоставление части полевых материалов.

Мишарина А.А., Широкова Е.И. Поле упругих напряжений Земли и механизм очагов землетрясений. Москва: Наука, 1972. $192 \mathrm{c}$. 
Переинтерпретация сейсмических материалов ГСЗ и гравитационное моделирование по профилям 25, 28 и 29 в Черном и Азовском морях. Геофиз. журн. 2008. Т. 30. № 5. C. $1-10$.

Бызова С. А. Некоторые вопросы тектоники Горного Крыма. Вестн. Моск. ун-та. Сер. 4. Геология. 1980. № 6. С. 15-25.

Вольфман Ю.М. Аеформационные режимы и кинематические обстановки новейшего тектонического разрывообразования в пределах Горного Крыма. 2. Геофиз. журн. 2015. T. 37. № 1. C. 100-120. doi: https://doi.org/ 10.24028/gzh.0203-3100.v37i1.2015.111328.

Гинтов О.Б. Полевая тектонофизика и ее применение при изучении деформаций земной коры Украины. Киев: Феникс, 2005. 572 с.

Гинтов О.Б., Вольфман Ю.М., Колесникова Е.Я., Муровская А. В. Тектонофизическая интерпретация механизмов очагов землетрясений системы Загрос. Геоgинамика и тектонофизика. 2014. Т. 5. № 1. С. 305-319. doi: 10.5800/GT-2014-5-1-0129.

Гобаренко В.С., Муровская А. В., Егорова Т.П., Шеремет E.E. Современные коллизионные процессы на северной окраине Черного моря. Геотектоника. 2016. № 4. С. 68-87. doi: 10.7868/S0016853X16040020.

Гончар В.В. К обоснованию механизма латеральной экструзии земной коры Горного Крыма. Геофиз. журн. 2015. Т. 37. № 4. C. 145-150. doi: https://doi.org/10.24028/gzh. 0203-3100.v37i4.2015.111135.

Гончар В.В. Коллизионная природа Крымского орогена - опыт исследования методом конечньх элементов. Геофиз. журн. 2013. T. 35. № 6. C. 148-164. doi: https://doi.org/ 10.24028/gzh.0203-3100.v35i6.2013.116526.

Костров Б.В. Сейсмический момент, энергия землетрясений и сейсмическое течение горных масс. Изв. АН СССР. Физика Земли. 1974. № 1. С. 23-40.

Милеев В.С., Розанов С. Б., Барабошкин Е.Ю., Шалимов И.В. Особенности внутренних деформаций аллохтонов Горного Крыма. Аокл. АН. 1998. Т. 358. № 2. С. 233-235.

Муратов М. В. (ред.). Геология СССР. Т. VIII.
Крым. Ч. 1. Геологическое описание. Москва: Недра, 1969. 576 с.

Муровская А. В. Поля напряжений и деформащионные режимы Западного Горного Крыма на альпийском этапе тектогенеза по тектонофизическим данным: Аис. ... канg. геол.-мин. наук. Киев, 2012. 146 с.

Муровская А., Ипполит Ж.-К., Шеремет Е., Егорова Т., Вольфман Ю., Колесникова К. $\triangle$ ефрормационные структуры и поля напряжений юго-западного Крыма в контексте эволюции Запално-Черноморского бассейна. Геояинаміка. 2014. № 2 (17). С. 53-68.

Осокина А.Н., Фрияман В.Н. Исследование закономерностей строения поля напряжений в окрестностях сдвигового разрыва с трением между берегами. В кн.: Поля напряжений и gеформаций в земной коре. Москва: Наука, 1987. С. 74-119.

Паталаха Е.И., Гончар В.В., Сенченков И.К., Червинко О.П. Инденторный механизм в геодинамике Крымско-Черноморского региона. Киев: Эмко, 2003. 226 с.

Пустовитенко Б. Г., Эреgжепов Э. Э. Очаговые параметры землетрясений КрымскоЧерноморского региона за 2016 год. Ученые записки Крымского феgерального университета имени В.И. Вернаgского. География. Геология. 2017. Т. 4 (70). № 4. С. 36-48.

Ребецкий Ю. А. Тектонические напряжения и прочность горных массивов. Москва: Наука, 2007. 406 с.

Туголесов А.А., Горшков А.С., Мейснер А.Б., Соловьев В.В., Хахалев В.И. Тектоника Мезо-кайнозойских отложений Черноморской впадины. Москва: Недра, 1985. 215 с.

Юguн В. В. Геодинамика Крыма. Симфрерополь: Аиайпи, 2011. 335 с.

Bott M. H.P., 1959. The mechanics of oblique slip faulting. Geol. Mag. (96), 109-117.

Byerlee J.D., 1978. Friction of Rocks. Pure Appl. Geophys. 116, 615-626.

Delvaux D., Sperner B., 2003. New aspects of tectonic stress inversion with reference to the TENSOR program. In: New insights into structural interpretation and modeling. Geol. Soc. London. Spec. Publ. 212, 75-100. 
Dinu C., Wong H.K., Tambrea D., Matenco L., 2005. Stratigraphic and structural characteristics of the Romanian Black Sea shelf. Tectonophysics $410(1-4), 417-435$. https://doi. org/10.1016/j.tecto.2005.04.012.

Espurt N., Hippolyte J. C., Kaymakci N., Sangu E., 2014. Lithospheric structural control on inversion of the southern margin of the Black Sea Basin, Central Pontides, Turkey. Lithosphere 6 (1), 26-34. http://doi.org/10.1130/L316.1.

Görür N., 1997. Cretaceous syn- to post-rift sedimentation on the southern continental margin of the Western Black Sea Basin. In: Robinson A. G. (ed.). Regional and petroleum geology of the Black Sea and surrounding region. AAPG Memoir. 68, P. 227-240.

Finetti I., Bricchi G., Del Ben A., Pipan M., Xuan $Z ., 1988$. Geophysical study of the Black Sea. Bollettino di Geofisica Teorica ed Applicata XXX (117-118), 197-324.

Hippolyte J. C., Espurt N., Kaymakci N., Sangu E., Müller C., 2016. Cross-sectional anatomy and geodynamic evolution of the Central Pontide orogenic belt (northern Turkey). Int. J. Earth Sci. 105 (1), 81-106. doi: 10.1007/ s00531-015-1170-6.

Hippolyte J. C., Müller C., Kaymakci N., Sangu E., 2010. Dating of the Black Sea Basin: new nannoplankton ages from its inverted margin in the Central Pontides (Turkey). In: M. Sosson, N. Kaymakci, R. Stephenson, F. Bergerat, $V$. Starostenko (eds). Sedimentary Basin Tectonics from the Black Sea and Caucasus to the Arabian Platform. Geol. Soc. London Spec. Publ. 340, 113-136. http://doi.org/10.1144/ SP340.7.

Khriachtchevskaia O., Stovba S., Stephenson R., 2010. Cretaceous-Neogene tectonic evolution of the northern margin of the Black Sea from seismic reflection data and tectonic subsidence analysis. In: M. Sosson, N. Kaymakci, R. Stephenson, F. Bergerat, V. Starostenko (eds). Sedimentary Basin Tectonics from the Black Sea and Caucasus to the Arabian Platform. Geol. Soc. London Spec. Publ. 340, 137-157. doi: 10.1144/SP340.8.

Munteanu I., Matenco L., Dinu C., Cloetingh S., 2011. Kinematics of back-arc inversion of the Western Black sea Basin. Tectonics 30, TC5004. doi: 10.1029/2011TC002865.
Nikishin A.M., Okay A.I., Tüysüz O., Demirer A., Amelin N., Petrov E., 2015a. The Black Sea basins structure and history: new model based on new deep penetration regional seismic data. Part 1: Basins structure and fill. Mar. Pet. Geol. (59), 638-655. https://doi.org/10.1016/ j.marpetgeo.2014.08.017.

Nikishin A.M., Okay A.I., Tüysüz O., Demirer A., Amelin N., Petrov E., 2015b. The Black Sea basins structure and history: new model based on new deep penetration regional seismic data. Part 2: Tectonic history and paleogeography. Mar. Pet. Geol. (59), 656-670. https: //doi.org/10.1016/j.marpetgeo.2014.08.018.

Nikishin A. M., Wannier M., Alekseev A.S., Almendiger O.A., Fokin P.A., Gabdullin R.R., Khudoley A. K., Kopaevich L.F., Mityukov A. V., Petrov E.I., Rubtsova E. V., 2017. Mesozoic to recent geological history of southern Crimea and the Eastern Black Sea region. In: M. Sosson, R. Stephenson, Sh. Adamia (eds). Tectonic Evolution of the Eastern Black Sea and Caucasus. Geol. Soc. London Spec. Publ. 428, $241-264$.

Okay A.I., Nikishin A. M., 2015. Tectonic evolution of the southern margin of Laurasia in the Black Sea region. Int. Geol. Rev. 57 (58), 1051-1076. http://dx.doi.org/10.1080/002 06814.2015.1010 609 .

Popadyuk I. V., Stovba S. M., Khriachtchevskaia O.I., 2013. The New Geological map of the Crimea Mountains by SPK - Geoservice as a new approach to understanding the Black Sea Region. Abstracts of Darius Programme, Eastern Black Sea - Caucasus Workshop, 24-25 June, 2013, Tbilisi, Georgia, P. 48-50.

Robinson A., Spadini G., Cloetingh S., Rudat J., 1995. Stratigraphic evolution of the Black Sea inferences from basin modelling. Mar. Pet. Geol. 12 (8), 821-835.

Saintot A., Angelier J., Chorowicz J., 1999. Mechanical significance of structural patterns identified by remote sensing studies: a multiscale analysis of tectonic structures in Crimea. Tectonophysics 313 (1-2), 187-218. doi: 10.1016/ S0040-1951(99)00196-1.

Sheremet Y., Sosson M., Müller C., Gintov O., Murovskaya A., Yegorova T., 2016a. Key problems of stratigraphy in the Eastern Crimea Peninsula: some insights from new dating and structural data. In: M. Sosson, R. Stephenson, 
Sh. Adamia (eds). Tectonic Evolution of the Eastern Black Sea and Caucasus. Geol. Soc. London Spec. Publ. 428, 265-305.

Sheremet Y., Sosson M., Ratzov G., Sydorenko G., Voitsitskiy Z., Yegorova T., Gintov O., Murovskaya A., 2016 b. An offshore-onland transect across the north-eastern Black Sea basin (Crimean margin): Evidence of Paleocene to Pliocene two-stage compression. Tectonophysics 688, 84-100. doi: 10.1016/j.tecto.2016.09.015.

Starostenko V.I., Sosson M., Farfulyak L., Gintov O. B., Yegorova T., Murovskaya A., Sheremet Ye., Legostaeva O., 2017. Deep crustal structure of the transition zone of the Scythian Plate and the East European Platform (DOBRE-5 profile): consequences of the Alpine tectonic evolution. Геофизический журнал 39 (4), 119-121.
Vavrychuk V., 2014. Iterative joint inversion for stress and fault orientations from focal mechanisms. Geophys. J. Int. 199, 69-77. doi: 10.1093/ gji/ggu224.

Yegorova T., Gobarenko V., 2010. Structure of the Earth's crust and upper mantle of the Westand East-Black Sea Basins revealed from geophysical data and its tectonic implications. In: M. Sosson, N. Kaymakci, R. Stephenson, F. Bergerat, V. Starostenko (eds). Sedimentary Basin Tectonics from the Black Sea and Caucasus to the Arabian Platform. Geol. Soc. London Spec. Publ. 340, 23-42. doi: 10.1144/SP340.3.

Zonenshain L.P., Le Pichon X., 1986. Deep basins of the Black Sea and Caspian Sea as remnants of Mesozoic. Tectonophysics $123(1), 181-$ 211. doi: 10.1016/0040-1951(86)90197-6.

\title{
Recent and paleo-stresses at the northern margin of the Black Sea and the Crimea Mountain in Meso-Cenozoic-Quarter (according to mechanisms of earthquakes foci and field tectonophysical data)
}

\author{
(C) A. Murovskaya, J.-C. Hippolyte, Ye. Sheremet, T. Yegorova, 2018
}

Recent stress fields at the northern margin of the Black Sea have been characterized on the base of 32 mechanisms of the earthquakes foci. Orientations of compression axes in the foci give evidence that present-day tectonic process takes place under conditions of compression and transpression. For 13 mechanisms located within the band between the southern cost of the Crimea and the base of the continental slope regional stress field has been estimated, which reflects deformational regime of horizontal stress in northwest-southeast direction. The results of specification of paleostresses fields and deformation regimes have been presented according to field tectonophysical observations in 105 sites. Interpretation has been fulfilled within the limits of two generalized stages: extension in the Early Cretaceous and compression in the Cenozoic-Quarter. Stress fields of inverse, nappe and strike-slip types have been attributed to the stage of Cenozoic compression. Generalized paths of compression have been plotted, which form fan-like pattern within the arc-like sector of the South Coast of the Crimea from cape Meganom to cape Ayu-Dag and change their direction from northeast to west-east. Averaged stress fields have been calculated, which are of inverse type in Sudak-Feodosian zone and are represented by strike-slip types for the central and western parts of the Mountain Crimea (MC). The southwestern part of the MC is characterized by strike-slip-type stress field with northwest-northeast direction of the compression axis. The stage of Cretaceous extension is characterized by stress fields of normal type. The southwestern part of MC is characterized by north-northeast-north-north-west trend of extension and for the central part of MC the northeast-south-west direction of extension has been obtained.

Key words: the Crimea, the Black Sea, mechanisms of earthquakes foci, stress field, deformational regime, kinematic analysis, Cenozoic compression. 


\section{References}

Afanasenkov A.P., Nikishin A. M., Obukhov A. N., 2007. Geological structure and hydrocarbon potential of the East-Black Sea region. Moscow: Nauchnyy Mir, 172 p. (in Russian).

Balakina L.M., Vvedenskaya A.V., Golubeva I. V., Misharina L.A., Shirokova E.I., 1972. The field of elastic stresses of the Earth and the mechanism of foci of earthquakes. Moscow: Nauka, 192 p. (in Russian).

Baranova E.P., Yegorova T.P., Omelchenko V.D., 2008. Reinterpretation of seismic materials of DSS and gravity modeling along the profiles 25, 28 and 29 in the Black Sea and the Azov Sea. Geofizicheskiy zhurnal 30 (5), 1-10 (in Russian).

Byzova S. L., 1980. Some issues of tectonics of the Mountainous Crimea. Vestnik Moskovskogo universiteta. Ser. 4. Geologiya (6), 15-25 (in Russian).

Volfman Yu.M., 2015. Deformation regimes and kinematic conditions of modern tectonic faulting within the limits of the Mountain Crimea. 2. Geofizicheskiy zhurnal 37(1), 100-120. (in Russian). doi: https://doi.org/10.24028/gzh. 0203-3100.v37i1.2015.111328.

Gintov O.B., 2005. Field tectonophysics and its application for the studies of deformations of the Earth's crust of Ukraine. Kiev: Feniks, 572 p. (in Russian).

Gintov O.B., Volfman Yu.M., Kolesnikova E. Ya., Murovskaya A. V., 2014. Tectonophysical interpretation of earthquake focal mechanisms of the Zagros system. Geodinamika i tektonofizika 5(1), 305-319 (in Russian). doi: 10.5800/ GT-2014-5-1-0129.

.Gobarenko V.S., Murovskaya A.V., Yegorova T.P., Sheremet E.E., 2016. Contemporary conflict processes on the northern outskirts of the Black Sea. Geotektonika (4), 68-87 (in Russian). doi: 10.7868/S0016853X16040020.

Gonchar V., 2015. On substantiation of mechanism of lateral extrusion of the crust of the Mountain Crimea. Geofizicheskiy zhurnal 37(4), 145-150 (in Russian). doi: https://doi.org/ 10.24028/gzh.0203-3100.v37i4.2015.111135.

Gonchar V.V., 2013. Collisional nature of the
Crimean orogen - the experience of the finite element method. Geofizicheskiy zhurnal 35(6), 148-164 (in Russian). doi: https://doi.org/10. 24028/gzh.0203-3100.v35i6.2013.116 526.

Kostrov B. V., 1974. Seismic moment, earthquake energy and seismic flow of mountain masses. Proceedings of the USSR Academy of Sciences. Izvestiya AN SSSR. Fizika Zemli (1), 2340 (in Russian).

Mileev V. S., Rozanov S. B., Baraboshkin E. Yu., Shalimov I. V., 1998. Peculiarities of internal deformations of allochthons in the Mountainous Crimea. Doklady Akademii nauk 358 (2), 233-235 (in Russian).

Muratov M. V. (ed.), 1969. Geology of the USSR. Vol. VIII. Crimea. Part 1. Geological description. Moscow: Nedra, 576 p. (in Russian).

Murovskaya A. V., 2012. Stress fields and deformation modes of the Western Mountainous Crimea in the Alpine stage of tectogenesis according to tectonophysical data: Dis. ... cand. geol. and min. sci. Kiev, 146 p. (in Russian).

Murovskaya A., Ippolit J.-C., Sheremet E., Yegorova T., Volfman Yu., Kolesnikova K., 2014. Deformational structures and stress fields of the south-western Crimea in the context of the evolution of Western Black Sea basin. Geodynamika (2), 53-68 (in Russian).

Osokina D.N., Fridman V.N., 1987. Investigation of the laws of the structure of the stress field in the vicinity of a shear discontinuity with friction between the banks. In: Fields of stresses and deformations in the Earth's crust. Moscow: Nauka, P. 74-119 (in Russian).

Patalaha E.I., Gonchar V. V., Senchenkov I.K., Chervinko O.P., 2003. Indenter mechanism in the geodynamics of the Crimean-Black Sea region. Kiev: Emko, 226 p. (in Russian).

Pustovitenko B. G., Eredzhepov E.E., 2017. Focal parameters of earthquakes in the Crimean-Black Sea region for 2016. Scientific notes of the Vernadsky Crimean Federal University. Geography. Geology 4 (4), 36-48 (in Russian).

Rebetskiy Yu.L., 2007. Tectonic stresses and strength of mountain massifs. Moscow: Nauka, 406 p. (in Russian). 
Tugolesov D.A., Gorshkov A.S., Meysner L.B., Solovyev V.V., Khakhalev V.I., 1985. Tecto-nics of the Mesozoic-Cenozoic deposits of the Black Sea basin. Moscow: Nedra, 215 p. (in Russian).

Yudin V.V., 2011. Geodynamics of the Crimea. Simferopol: Diaypi, 335 p. (in Russian).

Bott M. H.P., 1959. The mechanics of oblique slip faulting. Geol. Mag. (96), 109-117.

Byerlee J.D., 1978. Friction of Rocks. Pure Appl. Geophys. 116, 615-626.

Delvaux D., Sperner B., 2003. New aspects of tectonic stress inversion with reference to the TENSOR program. In: New insights into structural interpretation and modeling. Geol. Soc. London. Spec. Publ. 212, 75-100.

Dinu C., Wong H.K., Tambrea D., Matenco L., 2005. Stratigraphic and structural characteristics of the Romanian Black Sea shelf. Tectonophysics $410(1-4), 417-435$. https://doi. org/10.1016/j.tecto.2005.04.012.

Espurt N., Hippolyte J. C., Kaymakci N., Sangu E., 2014. Lithospheric structural control on inversion of the southern margin of the Black Sea Basin, Central Pontides, Turkey. Lithosphere 6 (1), 26-34. http://doi.org/10.1130/ L316.1.

Görür N., 1997. Cretaceous syn- to post-rift sedimentation on the southern continental margin of the Western Black Sea Basin. In: Robinson A. G. (ed.). Regional and petroleum geology of the Black Sea and surrounding region. AAPG Memoir. 68, P. 227-240.

Finetti I., Bricchi G., Del Ben A., Pipan M., Xuan $Z ., 1988$. Geophysical study of the Black Sea. Bollettino di Geofisica Teorica ed Applicata XXX (117-118), 197-324.

Hippolyte J. C., Espurt N., Kaymakci N., Sangu E., Müller C., 2016. Cross-sectional anatomy and geodynamic evolution of the Central Pontide orogenic belt (northern Turkey). Int. J. Earth Sci. 105(1), 81-106. doi: 10.1007/ s00531-015-1170-6.

Hippolyte J. C., Müller C., Kaymakci N., Sangu E., 2010. Dating of the Black Sea Basin: new nannoplankton ages from its inverted margin in the Central Pontides (Turkey). In: M. Sos- son, N. Kaymakci, R. Stephenson, F. Bergerat, $V$. Starostenko (eds). Sedimentary Basin Tectonics from the Black Sea and Caucasus to the Arabian Platform. Geol. Soc. London Spec. Publ. 340, 113-136. http://doi.org/10.1144/ SP340.7.

Khriachtchevskaia O., Stovba S., Stephenson R., 2010. Cretaceous-Neogene tectonic evolution of the northern margin of the Black Sea from seismic reflection data and tectonic subsidence analysis. In: M. Sosson, N. Kaymakci, R. Stephenson, F. Bergerat, V. Starostenko (eds). Sedimentary Basin Tectonics from the Black Sea and Caucasus to the Arabian Platform. Geol. Soc. London Spec. Publ. 340, 137-157. doi: 10.1144/SP340.8.

Munteanu I., Matenco L., Dinu C., Cloetingh S., 2011. Kinematics of back-arc inversion of the Western Black sea Basin. Tectonics 30, TC5004. doi: 10.1029/2011TC002865.

Nikishin A.M., Okay A.I., Tüysüz O., Demirer A., Amelin N., Petrov E., 2015a. The Black Sea basins structure and history: new model based on new deep penetration regional seismic data. Part 1: Basins structure and fill. Mar. Pet. Geol. (59), 638-655. https://doi.org/10.1016/ j.marpetgeo.2014.08.017.

Nikishin A.M., Okay A.I., Tüysüz O., Demirer A., Amelin N., Petrov E., 2015b. The Black Sea basins structure and history: new model based on new deep penetration regional seismic data. Part 2: Tectonic history and paleogeography. Mar. Pet. Geol. (59), 656-670. https: //doi.org/10.1016/j.marpetgeo.2014.08.018.

Nikishin A. M., Wannier M., Alekseev A.S., Almendiger O.A., Fokin P.A., Gabdullin R.R., Khudoley A. K., Kopaevich L.F., Mityukov A. V., Petrov E.I., Rubtsova E.V., 2017. Mesozoic to recent geological history of southern Crimea and the Eastern Black Sea region. In: M. Sosson, R. Stephenson, Sh. Adamia (eds). Tectonic Evolution of the Eastern Black Sea and Caucasus. Geol. Soc. London Spec. Publ. 428, $241-264$.

Okay A.I., Nikishin A. M., 2015. Tectonic evolution of the southern margin of Laurasia in the Black Sea region. Int. Geol. Rev. 57 (58), 1051-1076. http://dx.doi.org/10.1080/002 06814.2015.1010 609 .

Popadyuk I. V., Stovba S. M., Khriachtchevskaia O.I., 2013. The New Geological map of 
the Crimea Mountains by SPK - Geoservice as a new approach to understanding the Black Sea Region. Abstracts of Darius Programme, Eastern Black Sea - Caucasus Workshop, 2425 June, 2013, Tbilisi, Georgia, P. 48-50.

Robinson A., Spadini G., Cloetingh S., Rudat J., 1995. Stratigraphic evolution of the Black Sea inferences from basin modelling. Mar. Pet. Geol. $12(8), 821-835$.

Saintot A., Angelier J., Chorowicz J., 1999. Mechanical significance of structural patterns identified by remote sensing studies: a multiscale analysis of tectonic structures in Crimea. Tectonophysics 313 (1-2), 187-218. doi: 10.1016/ S0040-1951(99)00196-1.

Sheremet Y., Sosson M., Müller C., Gintov O., Murovskaya A., Yegorova T., 2016a. Key problems of stratigraphy in the Eastern Crimea Peninsula: some insights from new dating and structural data. In: M. Sosson, R. Stephenson, Sh. Adamia (eds). Tectonic Evolution of the Eastern Black Sea and Caucasus. Geol. Soc. London Spec. Publ. 428, 265-305.

Sheremet Y., Sosson M., Ratzov G., Sydorenko G., Voitsitskiy Z., Yegorova T., Gintov O., Murovskaya A., 2016 b. An offshore-onland transect across the north-eastern Black Sea basin (Cri- mean margin): Evidence of Paleocene to Pliocene two-stage compression. Tectonophysics 688, 84-100. doi: 10.1016/j.tecto.2016.09.015.

Starostenko V.I., Sosson M., Farfulyak L., Gintov O.B., Yegorova T., Murovskaya A., Sheremet Ye., Legostaeva O., 2017. Deep crustal structure of the transition zone of the Scythian Plate and the East European Platform (DOBRE-5 profile): consequences of the Alpine tectonic evolution. Геофизический журнал 39 (4), 119-121.

Vavrychuk V., 2014. Iterative joint inversion for stress and fault orientations from focal mechanisms. Geophys. J. Int. 199, 69-77. doi: 10.1093/ gji/ggu224.

Yegorova T., Gobarenko V., 2010. Structure of the Earth's crust and upper mantle of the Westand East-Black Sea Basins revealed from geophysical data and its tectonic implications. In: M. Sosson, N. Kaymakci, R. Stephenson, F. Bergerat, V. Starostenko (eds). Sedimentary Basin Tectonics from the Black Sea and Caucasus to the Arabian Platform. Geol. Soc. London Spec. Publ. 340, 23-42. doi: 10.1144/SP340.3.

Zonenshain L.P., Le Pichon X., 1986. Deep basins of the Black Sea and Caspian Sea as remnants of Mesozoic. Tectonophysics $123(1), 181-$ 211. doi: 10.1016/0040-1951(86)90197-6. 